\title{
Geochemical Enhancement Of Enhanced Geothermal System Reservoirs: An Integrated Field And Geochemical Approach
}

\author{
Final Technical Report \\ September 30, 2007
}

\section{DE-FG36-04G014292}

Principal Investigator: Joseph Moore; Energy and Geoscience Institute; 801-585-6931; jmoore@egi.utah.edu

Technical Contact Shirley Streff, 801-585-9763; Energy and Geoscience Institute; sstreff@egi.utah.edu

DOE Project Officer: Jay Nthwani; 303-275-4756; jay.nathwani@go.doe.gov

DOE Contract Spec: Pete Simon; 303-275-4787; pete.simon@go.doe.gov

\section{Introduction}

The geochemical effects of injecting fluids into geothermal reservoirs are poorly understood and may be significantly underestimated. Decreased performance of injection wells has been observed in several geothermal fields after only a few years of service, although the reason for these changes has only recently been established (McLin et al., 2006a). The goal of this project is to improve reservoir performance by understanding the effects of fluid injection on the reservoir and by providing solutions for mitigating these effects. The two geothermal fields that are the focus of this project are the Coso and Salton Sea geothermal fields, CA. Mineral deposition was hypothesized as the cause for declines in injection well performance.

These systems provide a unique opportunity to characterize injection-induced effects. During the initial phase of the project, rock samples from original and redrilled injection wells at Coso and Salton Sea were used to characterize the mineral and geochemical changes that occur as a result of injection. Samples from the original and redrilled injection wells at Coso were used to establish the mineral assemblages and their geochemical characteristics prior to injection. The results of these investigations were used to constrain numerical modeling of fluid-rock interactions and mineral changes in the near well bore environment. Future work includes predicting mineral deposition and dissolution in the reservoir rocks downstream of the injection wells.

\section{Project Team}

The members of the project team consist of Drs. J. Moore (Energy \& Geoscience Institute and D. Norman (New Mexico Institute of Mining and Technology) who serve as CoPrincipal Investigators, Dr. J. Park, a researcher at the New Mexico Institute of Mining and Technology and Ms. K. McLin, a Ph.D student at the University of Utah. CalEnergy Operating Corp., Calpine Corp. and Coso Operating Co. have generously provided 
samples and data for the project. Dr. J. Bowman (University of Utah) is providing additional assistance in the interpretation of the geochemical data..

\section{Work Plan}

The proposed work plan for this project is shown in Figure 1. The project was funded through year 2 and was successful in meeting its objectives to that point. During the second year of the project, DOE requested that Dr. Moore provide additional support to the Coso EGS program and the objectives of the project were modified. At the time the project was terminated at the end of year 2, the objectives of the project were to:

1. Provide petrologic and geochemical support to the Coso EGS project

2. Conduct geologic investigations of Coso well 46A-19RD.

3. Determine the effects of fluid injection on Coso reservoir rocks through examination of drill hole samples.

4. Utilize these observations to constrain predictions of fluid-rock interactions.

5. Improve reservoir performance by developing injection strategies for mitigating and reversing the potential effects of mineral deposition resulting from injection.

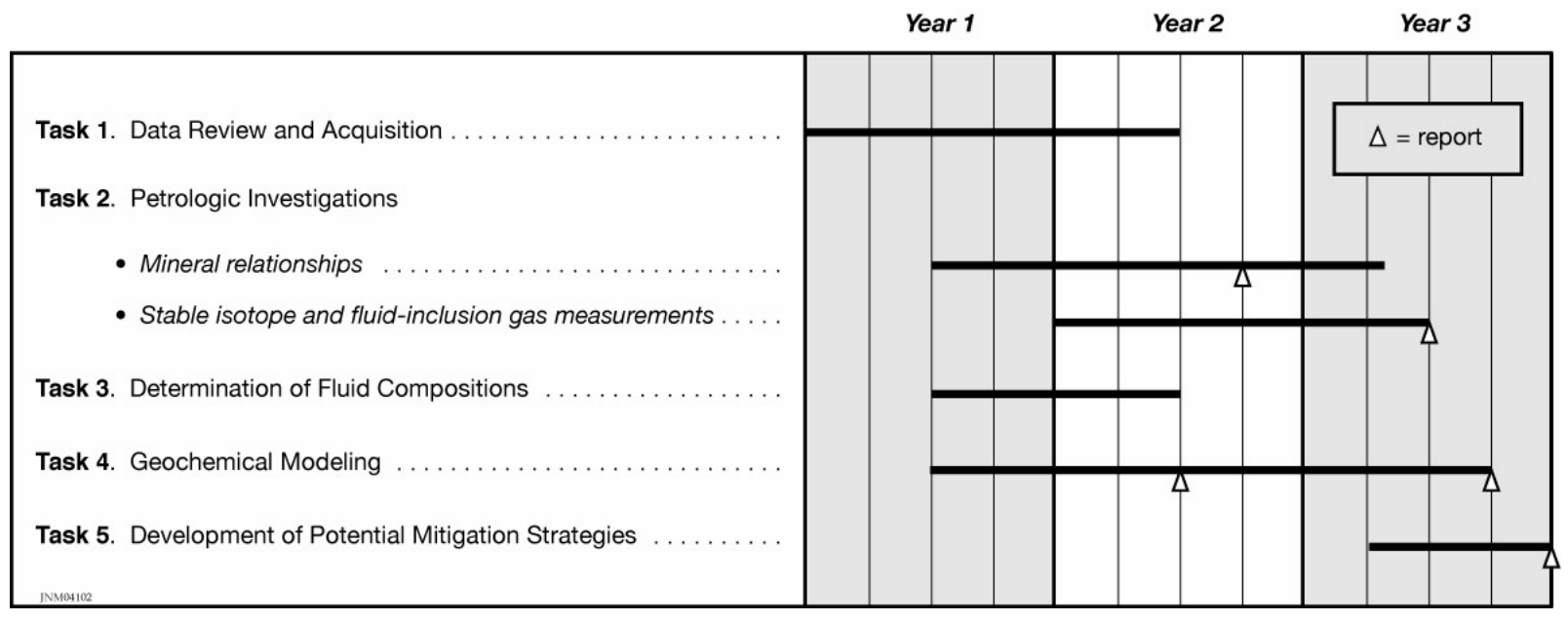

Fig. 1. Project work plan.

\section{Approach}

The basic approach of this study is to compare the mineral and geochemical signatures of the reservoir rock before and after injection. We will use samples from original injection wells to characterize rock conditions before injection began. At Coso, and the Salton Sea some of the original injection wells had to be redrilled because their performance had declined to the point where they could no longer accept the quantity of fluid that had to be injected. These declines occurred over a period of 5 to 7 years. Mineral deposition is the likely cause of their reduced performance. Samples from these redrilled injection wells, which were drilled adjacent to the original wells, will used to characterize the 
effects of injection. Because the injected fluids are not in equilibrium with the reservoir rocks, mineral precipitation and dissolution can be expected to occur.

\section{The Coso Geothermal System}

The Coso geothermal field is developed in Mesozoic granitic rocks of the Sierra Nevada Batholith on the western edge of the Basin and Range (Adams et al, 2000). The heat driving the geothermal activity is related to shallow intrusions that have given rise to 38 rhyolitic domes during the last million years. The reservoir host rocks range in composition from diorite to granite with varying degrees of alteration and veining (Kovac et al, 2005). Active and fossil fumaroles lie along a NE-SW trending belt that extends through Devil's Kitchen and Coso Hot Springs. On the eastern margin of the field, known as the East Flank, fossil sinter and travertine deposits are present (Adams et al, 2000). Geothermal power production has been sustained at 240 MWe since 1989. Between 1987 and 1993, six injection wells were drilled on the 68-20 pad and four were drilled on the 67-17 pad in the southern part of the field (Fig. 2 and 3, Table 1). Reservoir temperatures prior to injection ranged from approximately $205-240^{\circ} \mathrm{C}$. The temperatures of the fluids injected into 68-20 ranged from $110-120^{\circ} \mathrm{C}$. The injected fluids had silica contents ranging from 174 to $965 \mathrm{ppm}$ and were supersaturated in silica with respect to quartz, the stable silica phase in the reservoir (Table 2).

\section{Occurrence of Scale Deposits Within the Reservoir Rocks}

Cuttings from Coso injection wells have been examined at $3 \mathrm{~m}$ depth intervals. The rock type, the abundance of primary and secondary minerals, and the abundance, mineralogy, and paragenesis of the veins was documented at each interval. Thinly banded opaline silica was observed in the cuttings from 68-20RD and 68B-20RD, but not in the original drill holes or other wells. The banding and textural relationships suggest the silica represents fracture fillings and not alteration of preexisting minerals. The greatest density of silica precipitation was found in cuttings from depths of 2851-2900 ft. (869$884 \mathrm{~m}$ ) and 5610-5620 ft. (1710-1713 m) (Fig. 4 and 5). Samples of the precipitate from these two zones were analyzed using a Scanning Electron Microscope (SEM) and X-ray diffractometer. 
Table 1. Principal facts of Coso 68-20 and 67-17 pad injection wells.

\begin{tabular}{|c|c|c|c|c|}
\hline WELL & $\begin{array}{l}\text { TD } \\
\text { Ft } \\
\end{array}$ & $\begin{array}{c}\text { TVD } \\
\text { Ft } \\
\end{array}$ & $\begin{array}{c}\text { Completion } \\
\text { Date } \\
\end{array}$ & $\begin{array}{c}\text { Scale } \\
\text { Present } \\
\end{array}$ \\
\hline $68-20$ & 6485 (1977 m) & $6473(1973 \mathrm{~m})$ & 10/29/1987 & No \\
\hline 68-20RD & 7494 (2284 m) & $7462(2274 \mathrm{~m})$ & 5/8/1992 & Yes \\
\hline $68 \mathrm{~A}-20$ & 7905 (249 m) & 7608 (2319 m) & 7/2/1988 & No \\
\hline 68A-20RD & 7011 (2137 m) & $6918(2109 \mathrm{~m})$ & 9/14/1988 & No \\
\hline 68B-20 & $6782(2067$ m) & $6771(2064 \mathrm{~m})$ & 11/10/1988 & No \\
\hline 68B-20RD & 7058 (2151 m) & 7019 (2139 m) & 1/26/1993 & Yes \\
\hline 67-17RD & 96302935 m) & 9335 (2845 m) & 12/24/1991 & No \\
\hline 67A-17 & 9427 (2873 m) & 9199 (2804 m) & 8/10/1992 & No \\
\hline 67B-17 & $8900(2713 \mathrm{~m})$ & 8619 (2627 m) & 10/10/1994 & No \\
\hline 67C-17 & $7813(2381 \mathrm{~m})$ & 7646 (2331 m) & 1997 & No \\
\hline
\end{tabular}




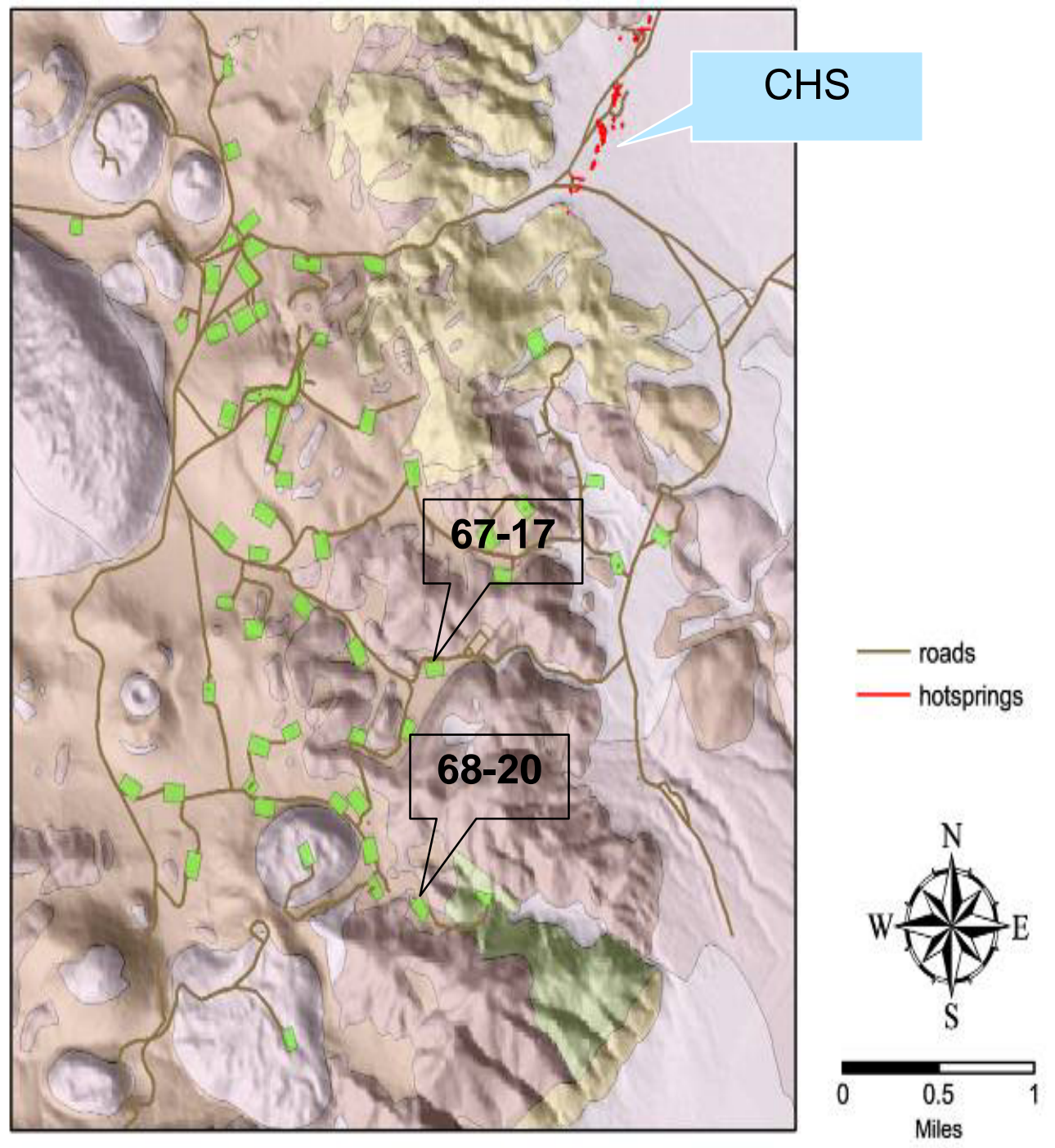

Fig. 2. Locations of the injection well sites. Green rectangles are well pads. CHS = Coso Hot Springs. 


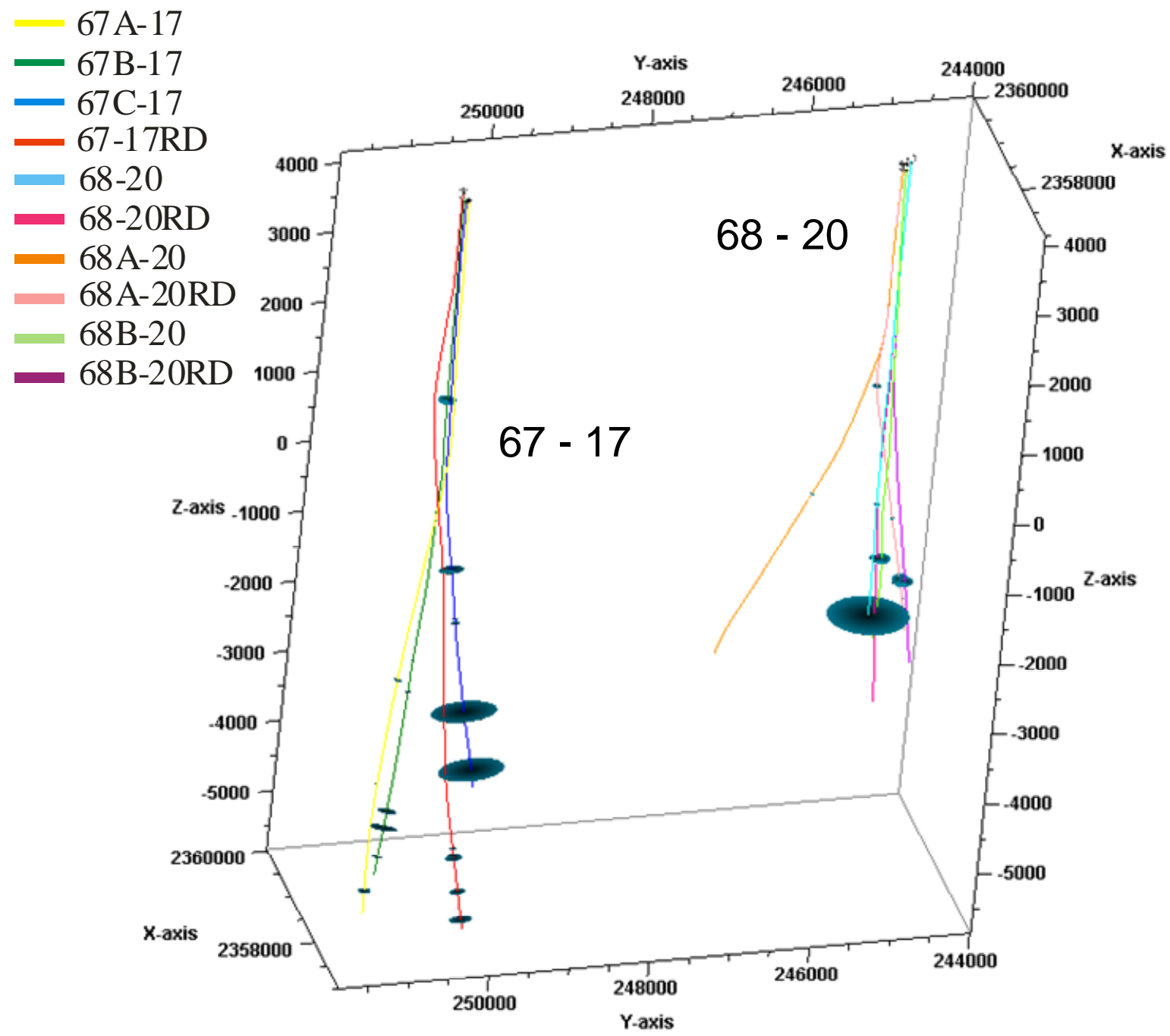

Fig. 3. Well trajectories and locations of lost circulation zones, shown as discs. The amount of fluid lost is represented by the size of the disc. Axes in feet. 
Table2. Injected fluid chemistry from well 68-20 and 67C-17. Analyses are in mg/kg. The fluids were injected at $110-120^{\circ} \mathrm{C}\left(220-240^{\circ} \mathrm{F}\right)$.

\begin{tabular}{|c|c|c|c|c|c|c|c|c|c|c|c|}
\hline Well & Date & Na & $\mathbf{K}$ & $\mathbf{C a}$ & $\mathbf{M g}$ & $\mathbf{F e}$ & $\mathbf{A l}$ & $\mathbf{S i O}_{2}$ & $\mathbf{B}$ & $\mathbf{L i}$ & $\mathbf{S r}$ \\
$68-20$ & $6 / 27 / 1988$ & 3340 & 725 & 78.1 & 8.7 & 33.2 & 10.4 & 555 & 99.7 & 37.2 & 3.3 \\
$68-20$ & $10 / 4 / 1988$ & 3520 & 941 & 64.4 & 0.27 & 0.49 & 0 & 965 & 116 & 47 & 3.8 \\
$68-20$ & $3 / 30 / 1989$ & 2897.17 & 362.27 & 19 & 0.08 & 0.3 & 0.37 & 617.14 & 87.99 & 24.57 & 2.79 \\
$68-20$ & $6 / 15 / 1989$ & 2993.2 & 464.5 & 22 & 0.09 & 0.13 & 0.56 & 677.76 & 83.02 & 40.74 & 2.6 \\
$68-20$ & $9 / 27 / 1989$ & 3652 & 501 & 29 & 0.14 & 0.01 & 0.25 & 173.51 & 119.21 & 33.14 & 3.67 \\
$68-20$ & $11 / 13 / 1989$ & 3470 & 579.57 & 25 & 0.12 & 2.53 & 0.63 & 697.51 & 114.14 & 31.39 & 3.9 \\
$68-20$ & $1 / 7 / 1990$ & 3540 & 590.16 & 24 & 0.15 & 1.88 & 0.39 & 826.4 & 128.95 & 35 & 3.62 \\
$68-20$ & $4 / 20 / 1990$ & 4283 & 633.44 & 36 & 0.65 & 84.1 & 1.58 & 747.15 & 126.64 & 35 & 6.01 \\
$68-20$ & $8 / 19 / 1990$ & 4010 & 739 & 32 & 0.14 & 2.85 & 0.5 & 936.23 & 141.8 & 40 & 3.66 \\
$68-20$ & $10 / 12 / 1990$ & 3908 & 672 & 38 & 0.15 & 0.33 & 0.33 & 701.49 & 121 & 36.7 & 4.88 \\
$68-20$ & $2 / 3 / 1991$ & 3774 & 595 & 47.3 & 0.46 & 0.12 & 0 & 545 & 109 & 31.3 & 4.42 \\
$68-20$ & $5 / 7 / 1991$ & 3480.37 & 605.28 & 37.16 & 0 & 0.88 & 0 & 592.51 & 112.68 & 28.16 & 4.95 \\
$68-20$ & $8 / 3 / 1991$ & 4192 & 590 & 130 & 3.94 & 6.5 & 1.01 & 620.4 & 130 & 30 & 8.23 \\
$68-20$ & $11 / 21 / 1991$ & 3508.3 & 601.35 & 46.4 & 0.14 & 0.3 & 0.43 & 545.92 & 125.16 & 30.78 & 5.51 \\
$68-20$ & $12 / 13 / 1996$ & 876 & 147 & 18 & ND & 1.7 & ND & 97 & 36 & 6.8 & 1.8 \\
& & & & & & & & & & & \\
$67 C-17$ & $1 / 23 / 98$ & 1670 & 350 & 39 & ND & ND & ND & 373 & 74 & 14 & 1670 \\
\hline
\end{tabular}

$\mathrm{ND}=$ not determined.

\begin{tabular}{|c|c|c|c|c|c|c|c|c|c|}
\hline Well & Date & As & Ba & HCO $_{3}$ & $\mathbf{C l}$ & $\mathbf{F}$ & SO $_{\mathbf{4}}$ & TDS & Lab pH \\
$68-20$ & $6 / 27 / 1988$ & 9.2 & 0.8 & 229 & 5770 & 2.4 & 73 & 10900 & 6.77 \\
$68-20$ & $10 / 4 / 1988$ & 11.2 & 116 & 77 & 6600 & 2.8 & 27 & 12300 & 7.2 \\
$68-20$ & $3 / 30 / 1989$ & 8.33 & 0.47 & 156 & 5015 & 2.33 & 80 & 9233 & 6.82 \\
$68-20$ & $6 / 15 / 1989$ & 10.94 & 0.4 & 195 & 5465 & 2.2 & 90 & & 7.25 \\
$68-20$ & $9 / 27 / 1989$ & 10.15 & 0.69 & 178 & 6440 & 1.7 & 95 & 11237 & 7.45 \\
$68-20$ & $11 / 13 / 1989$ & 6.9 & 0.56 & 168 & 5165 & 1.64 & 71 & & 6.83 \\
$68-20$ & $1 / 7 / 1990$ & 8.02 & 0.58 & 224.5 & 6018 & 2.3 & 44 & & 6.73 \\
$68-20$ & $4 / 20 / 1990$ & 26.24 & 0.9 & 141.5 & 5698 & 5.7 & 90 & & 6.723 \\
$68-20$ & $8 / 19 / 1990$ & 7.22 & 0.58 & 151 & 6958 & 3.01 & 27 & & 7.3 \\
$68-20$ & $10 / 12 / 1990$ & 8.8 & 0.9 & 161 & 6618 & 2.12 & 47 & & 8.2 \\
$68-20$ & $2 / 3 / 1991$ & 6.68 & 2.44 & 161 & 6340 & 2.48 & 99 & 11550 & 8.2 \\
$68-20$ & $5 / 7 / 1991$ & 2.85 & 0 & 174 & 6070 & 2.2 & 87 & 11000 & 8.3 \\
$68-20$ & $8 / 3 / 1991$ & 10.9 & 1.64 & 185.44 & 6855 & 2.8 & 53 & & 8.16 \\
$68-20$ & $11 / 21 / 1991$ & 6.1 & 0.8 & 143 & 6100 & 1.94 & 72 & 11500 & 8.25 \\
$68-20$ & $12 / 13 / 1996$ & 1.9 & 0.3 & 7.5 & 1412 & ND & 59 & 2766 & 6.17 \\
$67 C-17$ & $1 / 23 / 98$ & & & & & & & & \\
\end{tabular}

$\mathrm{ND}=$ not determined 


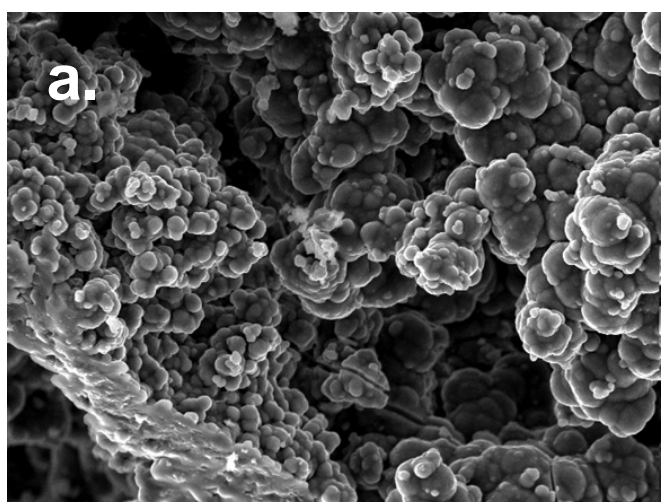

10 um

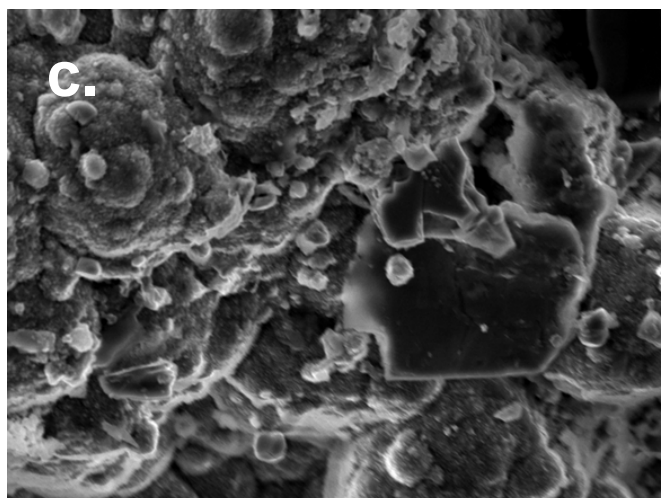

$10 \mathrm{um}$

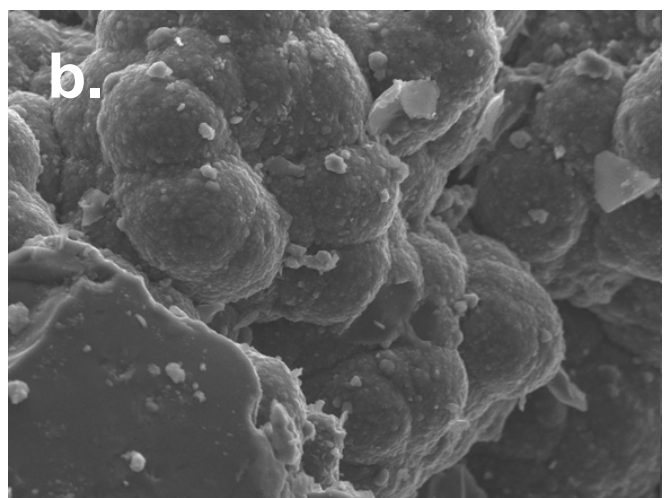

10 um

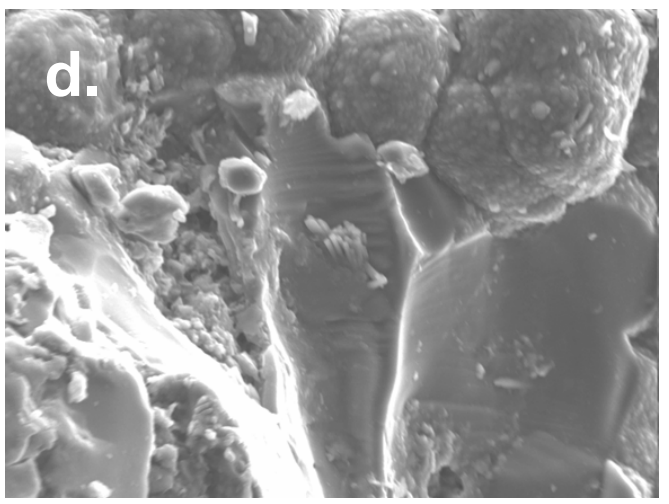

$10 \mathrm{um}$

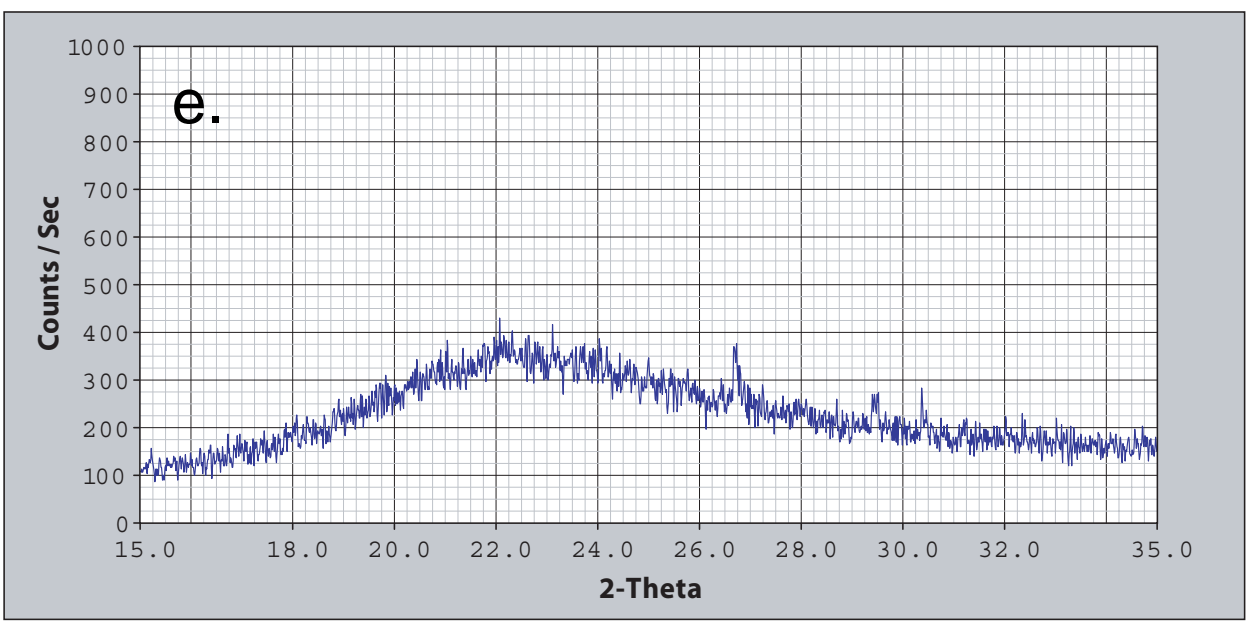

Fig. 4 (a).-(d). SEM images from 68-20RD at 2851-2900 ft. (869-884 m) depth. Opal-A spheres 1-2 mm in diameter seen in (a). coalesce to form $10 \mathrm{~mm}$ spheres and sheets (b, c and d).. (e). X-ray diffraction pattern of the scale showing a broad opal-A peak centered at $22^{\circ}$ 2-theta and quartz peaks at $21.5^{\circ}$ and $26.8^{\circ} 2$-theta. 


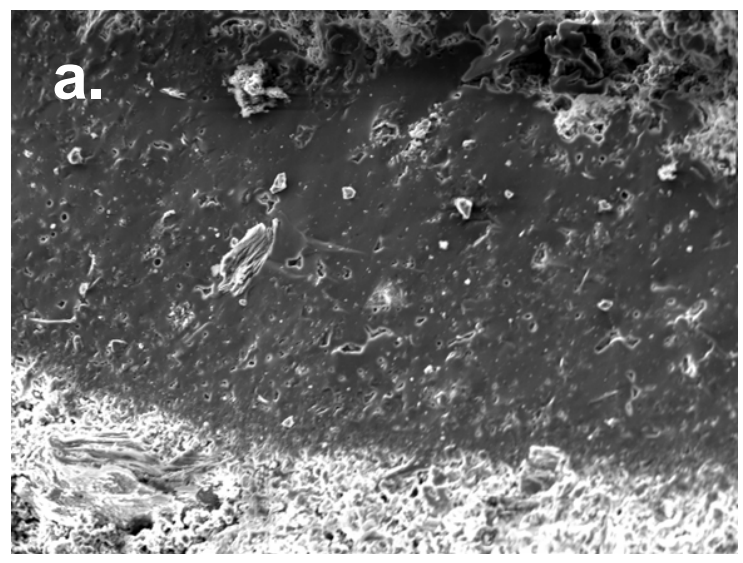

$20 \mu \mathrm{m}$
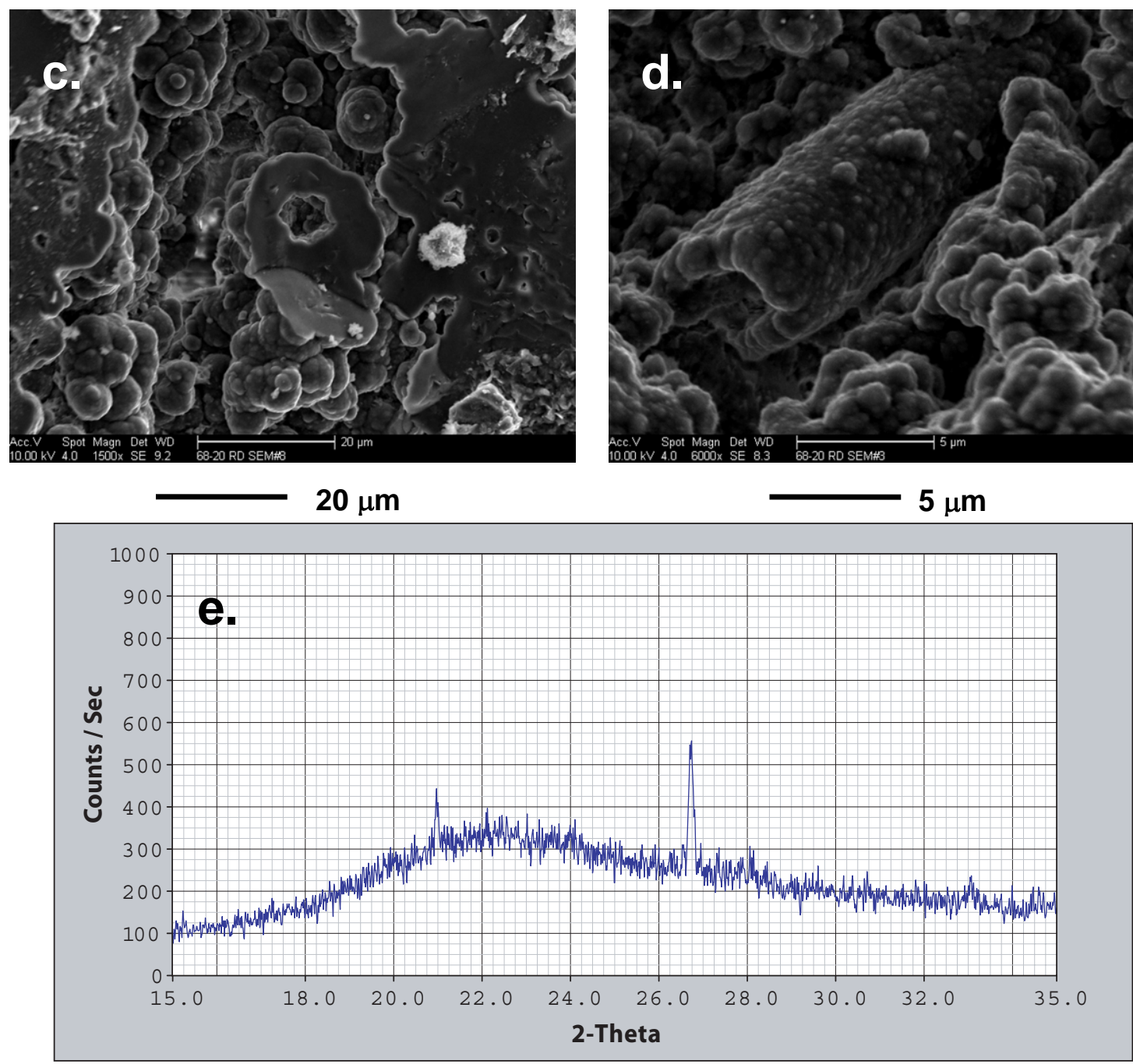

Fig. 5. (a).-(d). SEM images from 68-20RD at 5610-5620 ft. (1710-1713 m) depth. (a). Alternating silica layers with varying density and visible porosity. (b), (c). Silica spheres aligning to form strands (b). and sheets (c). (d). Tube structure covered with silica spheres. (e). X-ray diffraction pattern of the scale showing a broad opal-A peak centered at $22^{\circ} 2$-theta and quartz peaks at $21.5^{\circ}$ and $26.8^{\circ} 2$-theta. 
The silica deposits consist of opal-A spheres and plates. Figures 4 and 5 show the morphological progression associated with maturation of the deposits. Textural relationships shown in Figure 4A indicate the silica was deposited initially as spheres 1-2 $\mu \mathrm{m}$ in diameter. As the deposits mature, the spheres coalesce to form larger spheres up to $10 \mu \mathrm{m}$ in diameter (Fig. 4b). Further maturation is associated with the formation of plates and sheets (5b, c). Infilling of the spaces between spheres provides a possible explanation for the dense, smooth surfaces seen in Figures 4a. Traces of calcite locally coat the amorphous silica, suggesting it represents a later stage in the evolution of the deposits. The $\mathrm{SiO}_{2}$ maturation sequence observed at Coso is closely follows the changes observed in sinter deposits (Rodgers et al, 2004; Lynne and Campbell (2004).

An interesting and unusual feature of the silica deposit from 5610-5620 ft (1710-1713 m). $\mathrm{s}$ the tube like structure coated with silica spheres (Fig. 5d). Similar features, interpreted as silicified bacteria, have been observed in sinters from New Zealand (Rodgers et al, 2004).

The X-ray diffraction patterns of the samples are characterized by a broad peak centered at $22^{\circ}$ 2-theta representing opal $\mathrm{A}$, and peaks at $21.5^{\circ}$ and 26.80 2-theta representing quartz. Although quartz was not documented in the SEM images, it is possible that it represents fragments of the host reservoir rock. Alternatively, it is possible, but less likely, that the quartz represents maturation of the opal-A. Although quartz is common in mature sinter deposits, there is no evidence from the SEM or X-ray diffraction studies of intermediate stage in the Coso rocks.

\section{Fluid Inclusion Gas Analyses}

The gas contents and distribution of gaseous species in fluid inclusions were measured to determine if changes in the compositions of the inclusions could be used as a subtle indicator of interactions between the reservoir rocks and the injected injected fluids. It was hypothesized that the intrusive reservoir rocks would be characterized by fluid inclusions with high gas/water ratios. In contrast, the injected fluid has a low gas/water ratio because the fluid is flashed and the gases are transferred to the steam phase before the liquid is reinjected. Condensate that equilibrates with the atmosphere in the cooling tower will also have a relatively low gas/water ratio.

We are able to test this hypothesis by analysis of chips from 68-20, collected before injection began, and from 68-20 RD, drilled to replace the original well 5 years later (Dilley et al., 2006; Norman et al., 2007). Figure 6 compares the $\mathrm{H}_{2} \mathrm{O}$ and total gas distributions in 68-20 and 68-20 RD; ratios of $\mathrm{CO}_{2} / \mathrm{H}_{2} \mathrm{O}$ are shown in Figure 7. Fluid Inclusion Technologies performed the analyses on drill cuttings collected at $6 \mathrm{~m}$ intervals. Chips are crushed in vacuum and the volatiles released are analyzed by quadrupole mass spectrometry.

The analyses show that fluid inclusion gas/water ratios decreased by about $60 \%$ whereas the amount of inclusion water was about the same for both suites of chips. These changes are most pronounced in areas of high fluid flux where silica scale was deposited at depths 
of 2851-2900 (869-884 m) and 5610-5620 ft, (1710-1713 m) but the changes extend well beyond portions of the reservoir rock that contain the scale.

Differences between the two sets of analyses require the opening and loss of gaseous species from over $50 \%$ of the wall rock fluid inclusions. Furthermore the data show that the destruction of the original inclusions and formation of new fluid inclusions can occur rapidly, within a few years. Thus it is possible to use the bulk fluid inclusion gas analyses of drill cuttings to track the migration of the injected water. An important implication of this work is that the bulk-geochemical analyses will be biased towards the most recent event. Thus, the plots show that differences in the gas/water ratios provide a subtle record of interactions between the reservoir rocks and injected fluids, and that these changes can be used to track the movement of the injected fluids beyond areas where scale deposition has occurred.

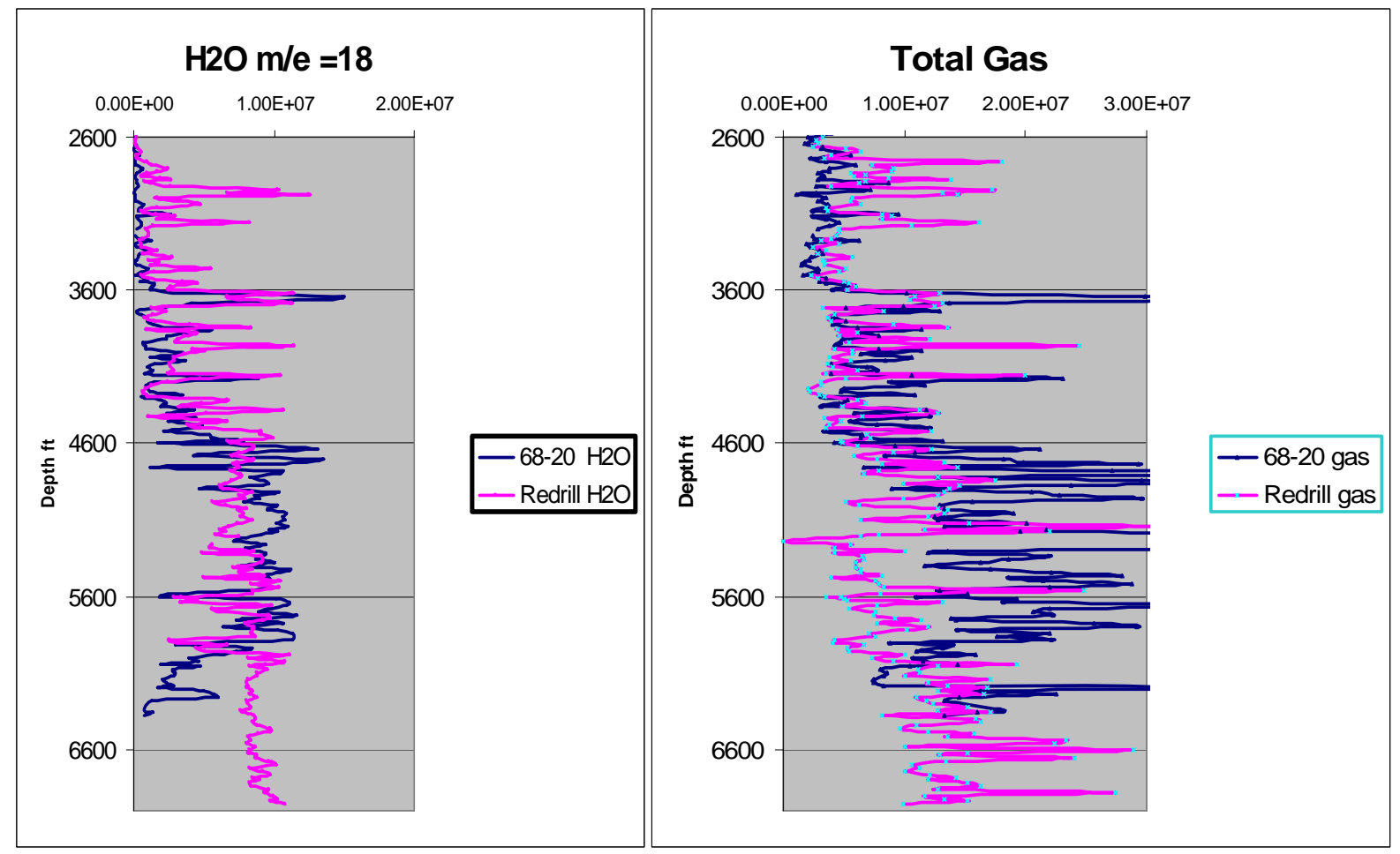

Fig. 6. Distribution of $\mathrm{H}_{2} \mathrm{O}$ and total gas in 68-20 and 68-20 RD. 


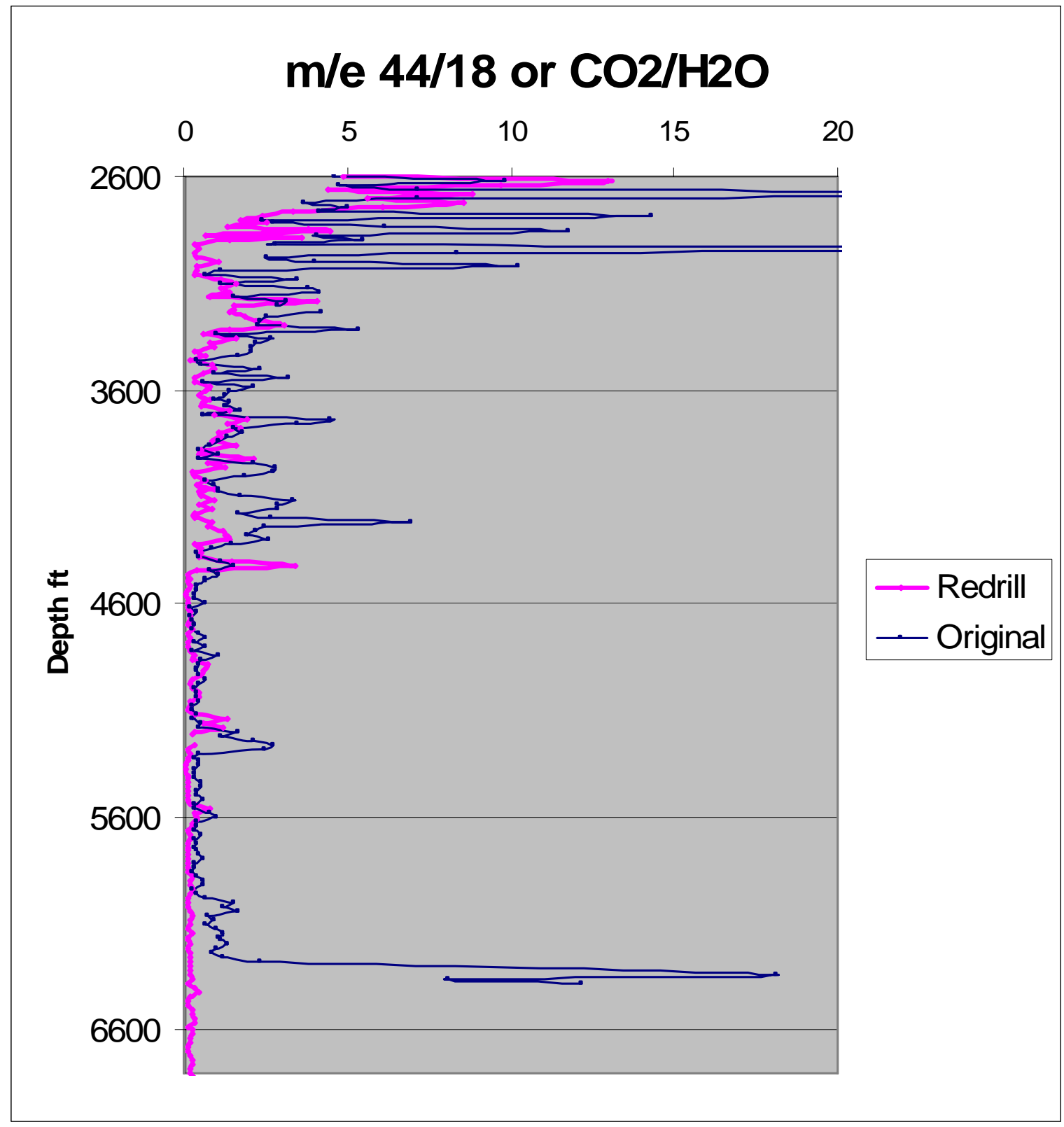

Fig. 7. Distribution of $\mathrm{CO}_{2} / \mathrm{H}_{2} \mathrm{O}$ ratios in $68-20$ and $68-20$ RD. 
Geochemical simulations were carried out by McLin et al. (2006b)using the nonisothermal reactive geochemical transport code TOUGHREACT (Xu and Pruess, 2001; Xu et al., 2004). This code was developed by introducing reactive chemistry into the framework of the existing multi-phase fluid and heat flow code TOUGH2 V2 (Pruess et al., 1999, see also http://www-esd.lbl.gov/TOUGHREACT/). Interactions between mineral assemblages and fluids can be modeled assuming local equilibrium or using kinetic rates. The gas phase can be chemically active. Precipitation and dissolution reactions can change formation porosity and permeability, as well as modify the unsaturated flow properties of the rock. This simulator can be applied to 1-, 2-, and 3dimensional porous and fractured media with physical and chemical heterogeneity. It can also deal with any number of species present in the liquid, solid, and gaseous phases.

The geometry and fluid and heat flow conditions are modeled after those described in Xu and Pruess (2004). A one-dimensional MINC (multiple interacting continua) model was used to represent the fractured rock. The MINC method can resolve "global" flow and diffusion of chemicals in the fractured rock and its interaction with "local" exchange between fractures and matrix. Details on the MINC method for reactive geochemical transport are described by $\mathrm{Xu}$ and Pruess (2001). In the simulations we considered interactions with: 1) a zone representing the relatively impermeable, unaltered host rock; and 2) altered, fractured, and veined host rock. In addition we considered two different rock types, diorite and granodiorite, which are the dominant lithologies affected by the injected fluid and where silica deposition has occurred. The parameters used in the models are shown in Table 3. A density of $2650 \mathrm{~kg}^{*} \mathrm{~m}^{-3}$, heat capacity of $1000 \mathrm{~J}^{*} \mathrm{~kg}^{-1} \mathrm{~K}^{-1}$, and diffusivity of $10^{-9} \mathrm{~m}^{-2} \mathrm{~s}^{-1}$ were used for all zones. The cubic law was used to define the porosity-permeability relationship in both zones (Xu et al., 2004). The model generates changes in porosity and permeability based on changes in mineral abundances.

Table 3. Parameters used in the numerical simulations.

\begin{tabular}{|l|c|c|c|}
\hline Parameters & Fracture & $\begin{array}{c}\text { Average Weakly- } \\
\text { Altered Granodiorite }\end{array}$ & $\begin{array}{c}\text { Average Weakly- } \\
\text { Altered Diorite }\end{array}$ \\
\hline Volume $\left(\mathrm{m}^{3}\right)$ & 0.1 & 0.9 & 0.9 \\
\hline Permeability $\left(\mathrm{m}^{2}\right)$ & $2.0 \mathrm{E}-12$ & $2.0 \mathrm{E}-18$ & $2.0 \mathrm{E}-15$ \\
\hline Porosity & 0.10 & 0.02 & .05 \\
\hline $\begin{array}{l}\text { Thermal Conductivity } \\
\left(\mathrm{W}^{*} \mathrm{~m}^{-1} \mathrm{~K}^{-1}\right)\end{array}$ & 2.9 & 3.0 & 3.0 \\
\hline Tortuosity & 0.3 & 0.1 & 0.1 \\
\hline
\end{tabular}

The reservoir rocks at a depth of $878 \mathrm{~m}$ in 68-20RD are dominated by hornblende biotite quartz diorite. Biotite granodiorite dominates at $1710 \mathrm{~m}$. The mineralogical 
compositions of these rocks were estimated from thin section observations of samples from 68-20RD and from X-ray diffraction and thin section studies of East Flank wells by Kovac et al (2005) and Lutz and Moore (1997). Both rock types are only weakly altered in 68-20RD. Veining is especially weak in the diorite at $878 \mathrm{~m}$; consequently the fracture zone was modeled as nearly empty. The deeper granodiorite was contains quartz, calcite and chlorite veins, as shown in Table 4.

Table 4. Mineralogy of the reservoir rocks.

\begin{tabular}{|l|c|c|c|c|}
\hline \multirow{4}{*}{ Mineral } & \multicolumn{3}{|c|}{ Volume Fraction of Solid Rock } \\
\cline { 2 - 5 } & \multicolumn{2}{|c|}{$\begin{array}{c}\text { 1710 m: } \\
\text { Granodiorite-hosted }\end{array}$} & \multicolumn{2}{c|}{$\begin{array}{c}878 \mathrm{~m}: \\
\text { Diorite-hosted }\end{array}$} \\
\cline { 2 - 5 } & $\begin{array}{c}\text { Average Weakly- } \\
\text { Altered Granodiorite }\end{array}$ & Fracture & $\begin{array}{c}\text { Average } \\
\text { Weakly- } \\
\text { Altered } \\
\text { Diorite }\end{array}$ & Fracture \\
\hline Quartz & 0.34 & .05 & .135 & \\
\hline Potassium Feldspar & 0.17 & & .045 & \\
\hline Chlorite & 0.02 & .01 & .01 & \\
\hline Illite & 0.03 & & 0.00 & \\
\hline Calcite & 0.02 & .04 & .025 & .009 \\
\hline Anorthite & 0.33 & & .038 & \\
\hline Annite & 0.06 & & 0.15 & \\
\hline
\end{tabular}

Mineral dissolution and precipitation are considered under kinetic constraints. The general kinetic rate expression used in TOUGHREACT (Xu et al., 2004) is given as follows:

$\mathrm{r}_{\mathrm{m}}= \pm \mathrm{k}_{\mathrm{m}} \mathrm{A}_{\mathrm{m}} \mathrm{a}_{\mathrm{H}+}{ }^{\mathrm{n}}\left|1-\mathrm{Q}_{\mathrm{m}} / \mathrm{K}_{\mathrm{m}}\right|$

where $\mathrm{m}$ is the mineral index, $\mathrm{r}_{\mathrm{m}}$ is the dissolution/precipitation rate, (positive for dissolution, negative for precipitation), $\mathrm{k}_{\mathrm{m}}$ is the rate constant (moles per unit mineral surface area and unit time) which is temperature-dependent, $A_{m}$ is the specific reactive surface area per $\mathrm{kg}$ of $\mathrm{H}_{2} \mathrm{O}$, $\mathrm{a}_{\mathrm{H}^{+}}$is the activity of $\mathrm{H}^{+}$, and $\mathrm{n}$ is an empirical reaction order accounting for catalysis by $\mathrm{H}^{+}$in solution. $\mathrm{K}_{\mathrm{m}}$ is the equilibrium constant for the mineralwater reaction written for the destruction of one mole of mineral $m, Q_{m}$ is the ion activity product. The temperature dependence of the reaction rate constant can be expressed as:

$\mathrm{k}=\mathrm{k}_{25} \exp \left[-\mathrm{E}_{\mathrm{a}} / \mathrm{R}(1 / \mathrm{T}-1 / 298.15)\right]$

where $E_{a}$ is the activation energy, $k_{25}$ is the rate constant at $25^{\circ} \mathrm{C}, \mathrm{R}$ is the universal gas constant, and $\mathrm{T}$ is absolute temperature. Table 5 shows the parameters used in the kinetic rate expression. 
Table 5. Parameters used in the kinetic rate expression

\begin{tabular}{|c|c|c|c|c|}
\hline Mineral & $\begin{array}{c}\mathrm{k}_{25} \\
\left(\text { moles }^{-2} \mathrm{~s}^{-1}\right)\end{array}$ & $\begin{array}{c}\mathrm{E}_{\mathrm{a}} \\
(\mathrm{KJ} / \mathrm{mole})\end{array}$ & $\begin{array}{c}\mathrm{n} \\
(\mathrm{rxn} . \text { order })\end{array}$ & $\begin{array}{c}\text { Surface Area } \\
\left(\mathrm{cm}^{2} / \mathrm{g}\right)\end{array}$ \\
\hline Quartz & $1.2589 \mathrm{E}-14$ & 87.5 & 0 & 9.8 \\
\hline Am. Silica & $7.3200 \mathrm{E}-13$ & 60.9 & 0 & $1.0 \mathrm{E} 6$ \\
& $1.0000 \mathrm{E}-10$ & 0.00 & 0 & $1.0 \mathrm{E} 6$ \\
\hline K-feldspar & $1.0000 \mathrm{E}-12$ & 57.78 & 0 & 9.8 \\
\hline Anorthite & $1.0000 \mathrm{E}-12$ & 57.78 & 0 & 9.8 \\
\hline Na-smectite & $1.0000 \mathrm{E}-14$ & 58.62 & 0 & 151.63 \\
\hline Ca-smectite & $1.0000 \mathrm{E}-14$ & 58.62 & 0 & 151.63 \\
\hline Illite & $1.0000 \mathrm{E}-14$ & 58.62 & 0 & 151.63 \\
\hline Annite & $2.5119 \mathrm{E}-15$ & 66.20 & 1 & 9.8 \\
& $2.5119 \mathrm{E}-15$ & 66.20 & 0 & 9.8 \\
\hline Calcite & $6.9183 \mathrm{E}-2$ & 18.98 & 1 & 9.8 \\
& $6.4565 \mathrm{E}-7$ & 62.76 & 0 & 9.8 \\
\hline Dolomite & $1.0233 \mathrm{E}-3$ & 20.90 & 1 & 9.8 \\
& $4.4668 \mathrm{E}-10$ & 62.76 & 0 & 9.8 \\
\hline Chlorite & $2.5119 \mathrm{E}-12$ & 62.76 & 0 & 151.63 \\
\hline
\end{tabular}

The composition of the reservoir fluid was estimated from the composition of an East Flank well (Table 6). Initial fluid compositions within the fracture and host rock were calculated by equilibrating the reservoir fluid composition with each rock's mineralogical composition at $275^{\circ} \mathrm{C}$. An example injection fluid composition that is relatively enriched in $\mathrm{Na}^{+}, \mathrm{Cl}^{-}$, and $\mathrm{SiO}_{2(\text { aq) }}$ was chosen as the trial injection water (Table 6). The injectate composition was not allowed to change over time.

Table 6. Compositions of reservoir and injected water used in the simulations.

\begin{tabular}{|c|c|c|}
\hline Chemical Component & Reservoir (Mol/kg) & Injection (Mol $/ \mathrm{kg})$ \\
\hline $\mathrm{SiO}_{2}$ & $1.30 \mathrm{E}-2$ & $9.96 \mathrm{E}-03$ \\
\hline $\mathrm{B}(\mathrm{OH})_{3}$ & $8.42 \mathrm{E}-3$ & $1.01 \mathrm{E}-02$ \\
\hline $\mathrm{Na}^{+}$ & $9.50 \mathrm{E}-2$ & $1.46 \mathrm{E}-01$ \\
\hline $\mathrm{K}^{+}$ & $1.20 \mathrm{E}-2$ & $1.42 \mathrm{E}-02$ \\
\hline $\mathrm{Li}^{+}$ & $2.45 \mathrm{E}-3$ & $4.44 \mathrm{E}-03$ \\
\hline $\mathrm{Ca}^{2+}$ & $9.55 \mathrm{E}-4$ & $1.07 \mathrm{E}-03$ \\
\hline $\mathrm{Mg}^{2+}$ & $4.12 \mathrm{E}-6$ & $2.22 \mathrm{E}-2$ \\
\hline $\mathrm{Sr}^{2+}$ & $3.60 \mathrm{E}-5$ & $5.00 \mathrm{E}-2$ \\
\hline $\mathrm{Cl}^{-}$ & $1.10 \mathrm{E}-1$ & $1.60 \mathrm{E}-01$ \\
\hline $\mathrm{F}^{-}$ & $1.47 \mathrm{E}-4$ & $1.15 \mathrm{E}-04$ \\
\hline $\mathrm{HCO}_{3}{ }^{-}$ & $1.10 \mathrm{E}-3$ & $2.48 \mathrm{E}-03$ \\
\hline $\mathrm{SO}_{4}^{-}$ & $3.12 \mathrm{E}-4$ & $6.97 \mathrm{E}-04$ \\
\hline $\mathrm{HS}^{-}$ & $3.02 \mathrm{E}-5$ & \\
\hline $\mathrm{CH}$ & $6.25 \mathrm{E}-10$ & \\
\hline $\mathrm{pH}$ & 6.84 & 6.47 \\
\hline $\mathrm{As}$ & & $1.16 \mathrm{E}-04$ \\
\hline
\end{tabular}


For the initial modeling, a one-dimensional multiple interacting continua (MINC) model was used. This conceptual model considers a one dimensional flow tube between the injection and production wells, which is a small sub-volume of the more extensive threedimensional reservoir. The initial reservoir conditions were $275^{\circ} \mathrm{C}$ and $30 \mathrm{MPa}$ pressure. An over-pressure of $2 \mathrm{MPa}$ was applied to the injection site. The model is based on conditions during nearly continuous injection over seven years. The control case model uses measured, observed, and estimated parameters from Lutz and Moore (1997), Kovac et al (2005), and McLin et al (2006). The simulations were run to a total time of 7 years. Changes in fluid $\mathrm{pH}$, fracture porosity, fracture permeability, fluid temperature, and mineral abundances were monitored out to a distance of $594 \mathrm{~m}$ from the injection well. Mineral abundance changes, as changes in volume fraction for quartz, potassium feldspar, chlorite, illite, Na-smectite, Ca-smectite, calcite, dolomite, anorthite, biotite, and amorphous silica were determined. Amorphous silica, calcite, and quartz displayed the most significant changes. Changes in porosity were calculated as a function of mineral dissolution and precipitation. A porosity increase indicates that mineral dissolution is dominant, while a porosity decrease occurs when precipitation dominates. Changes in permeability were calculated from changes in porosity as described above.

In the modeled control case at both depths, amorphous silica precipitates soon after injection begins, followed by calcite and a very minor amount of quartz (Fig. 8), consistent with observed mineral deposits in the rocks. Amorphous silica deposition did not occur in the case where silica concentration was decreased in the injected fluid by an order of magnitude (Fig. 8c, 8e).

The majority of amorphous silica precipitated within a few meters of the well and a period of one year (Fig. 9). Mineral deposition is accompanied by significant porosity and permeability decreases within a few meters of the well over the same time period. Calcite also precipitates near the injection well. These results are consistent with the rapid (within a few months) decline in injectivity experienced by well 68-20 (Fig. 10). As predicted, amorphous silica was observed only within a few meters of the original well. Thus the modeled results closely simulate the observed mineral paragenesis and abundances based on analyses of the cuttings.

The effects of modifying the $\mathrm{pH}$ of the injection fluid, from acidic to basic, to mitigate the effects of silica deposition were investigated by Park et al. (2006). Acid injection reduces the kinetic rate of silica precipitation by reducing the $\mathrm{pH}$. Although this inhibits $\mathrm{SiO}_{2}$ deposition in the immediate vicinity of the injection well, deposition of $\mathrm{SiO}_{2}$ can still be expected at greater distances. Injection of a basic solution will lead to $\mathrm{SiO}_{2}$ undersaturation and dissolution by the formation of $\mathrm{NaHSiO}_{3}$. Thus alternating the $\mathrm{pH}$ of the injected fluid may lead to enchanced permeabilities over time. 

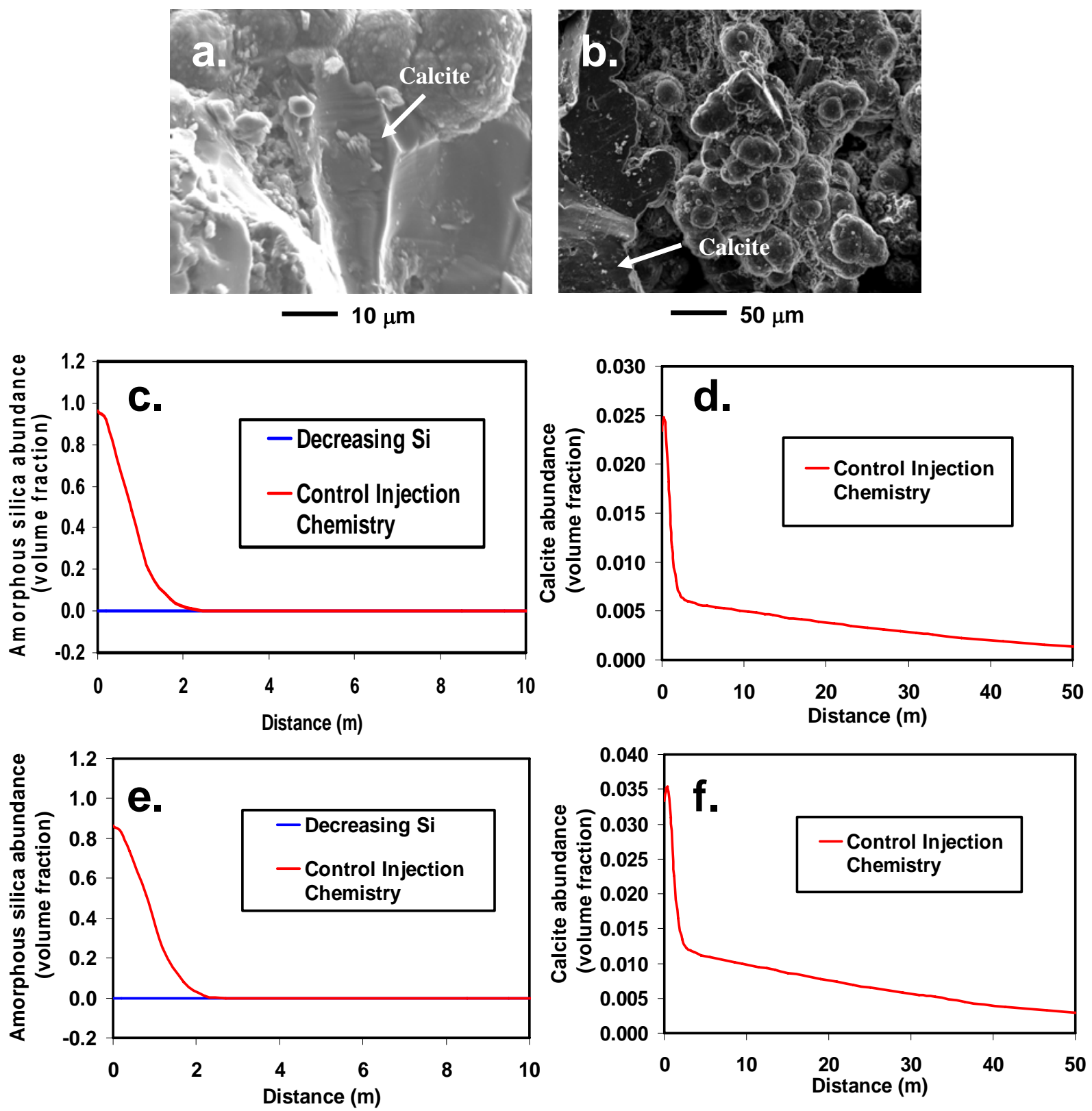

Fig. 8. (a). SEM image of opal-A and calcite from the depth interval 869-884 m. (b). SEM image of opal-A with small white calcite crystals from the depth interval 1710-1713 m. (c). and (d). Modeled results for a depth of $878 \mathrm{~m}$ showing amorphous silica (c) and calcite (d) as a function of distance in meters. (e) and (f) Modeled results for a depth of $1710 \mathrm{~m}$ showing amorphous silica (e) and calcite (f) as a function of distance in meters. 

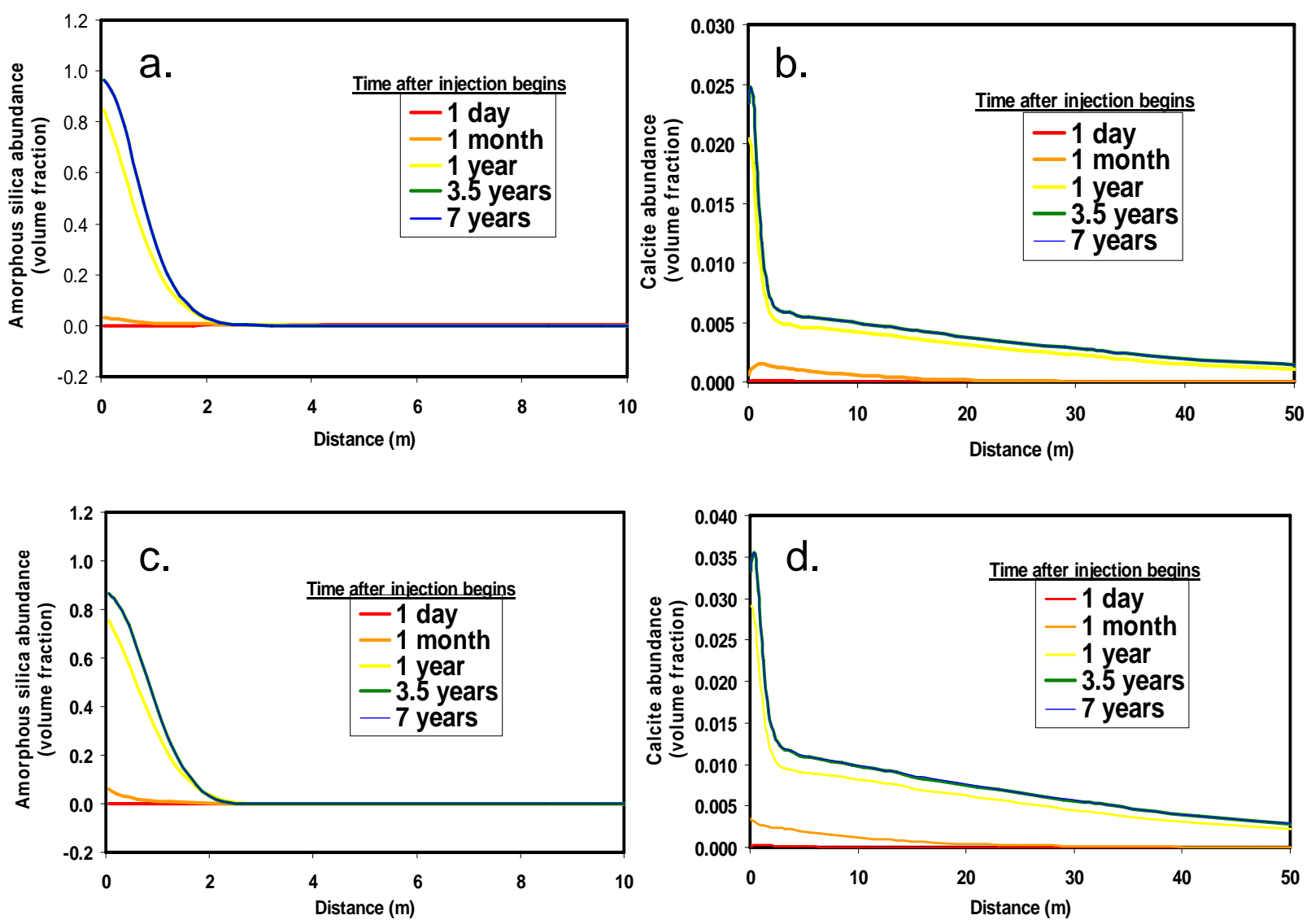

Fig. 9. Modeled results (a). and (b) from $878 \mathrm{~m}$ and (c), (d) from $1710 \mathrm{~m}$ showing amorphous silica and calcite as a function of distance in meters for various time periods over seven years.

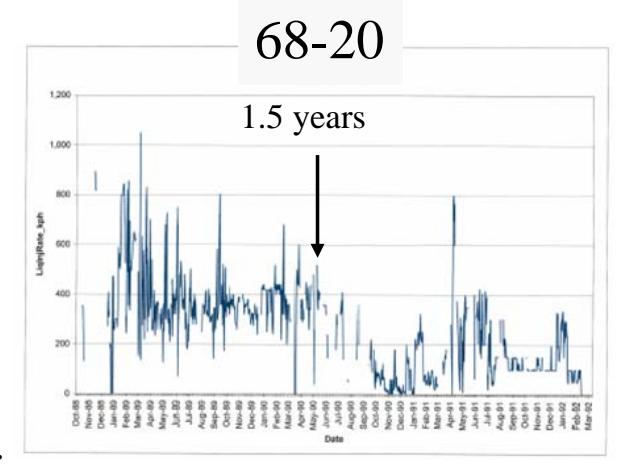

Fig. 10. Injection history of the original injection well 68-20. 


\section{Petrologic Investigations of Well 46A-19RD}

Detailed petrographic studies of well 46A-19RD have been conducted to determine the regions that are most likely to fail during stimulation (Kovac et al., 2006). Rock type, the location and paragenesis of the hydrothermal mineral assemblages, intensity of hydrothermal alteration and the locations of past fracture zones and their relationships to zones of fluid flow have been defined. Well 46A-19RD is among the hottest of the wells drilled at Coso, reaching temperatures in excess of $300^{\circ} \mathrm{C}$ (Fig. 11).

The rock types found in this well include quartz diorite, granodiorite, granite, and granophyre. In general, the lithologies encountered in this well are similar to those of other Coso wells with the exception of the granophyre, which has not been identified in any of the other wells studied so far.

Figure 11 shows that quartz diorite is the most common rock in the upper 11,500 $\mathrm{ft}$ (3505 m)and that at greater depths, granodiorite is the dominant rock type. Generally, the granodiorite in this well is more altered and veined than in the East Flank wells. The deep portion of the well also contained several zones of strong pervasive alteration, labeled 'alteration zones' by the mudloggers. 


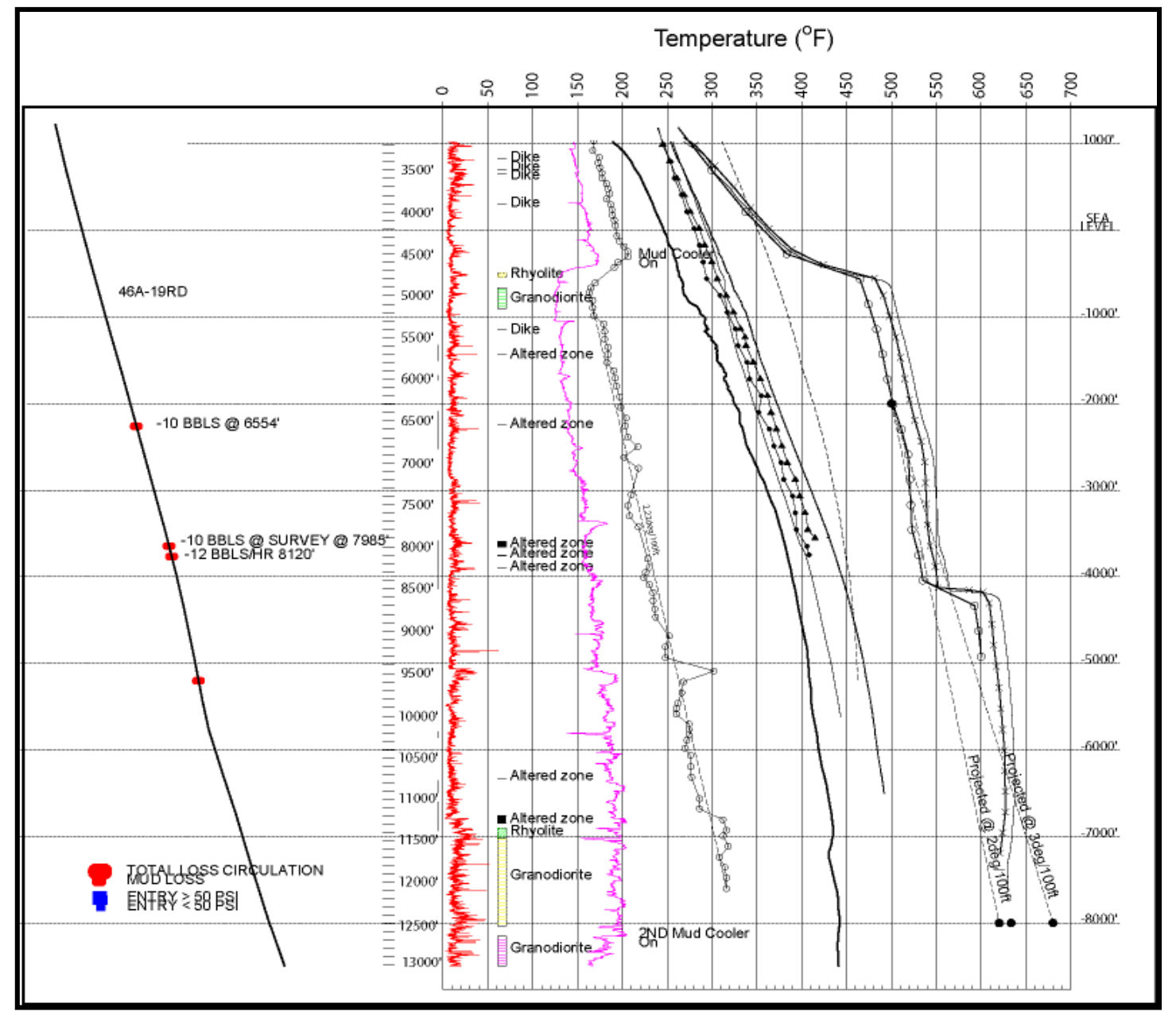

Fig. 11. The summary log for well 46A-19RD. Note the lack of lost circulation zones in the deep portion of the well. Also note the altered zones. See text for discussion. 

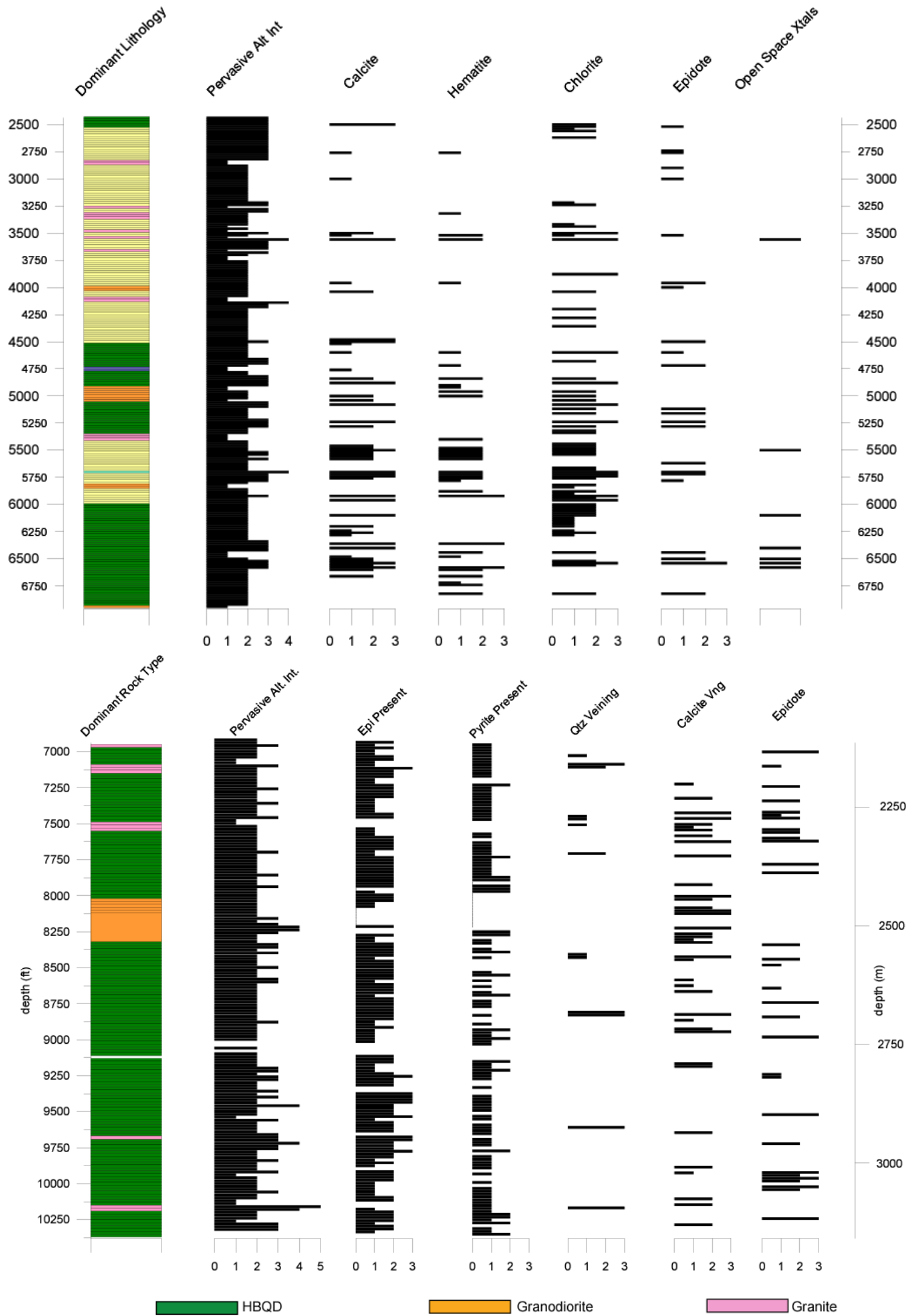


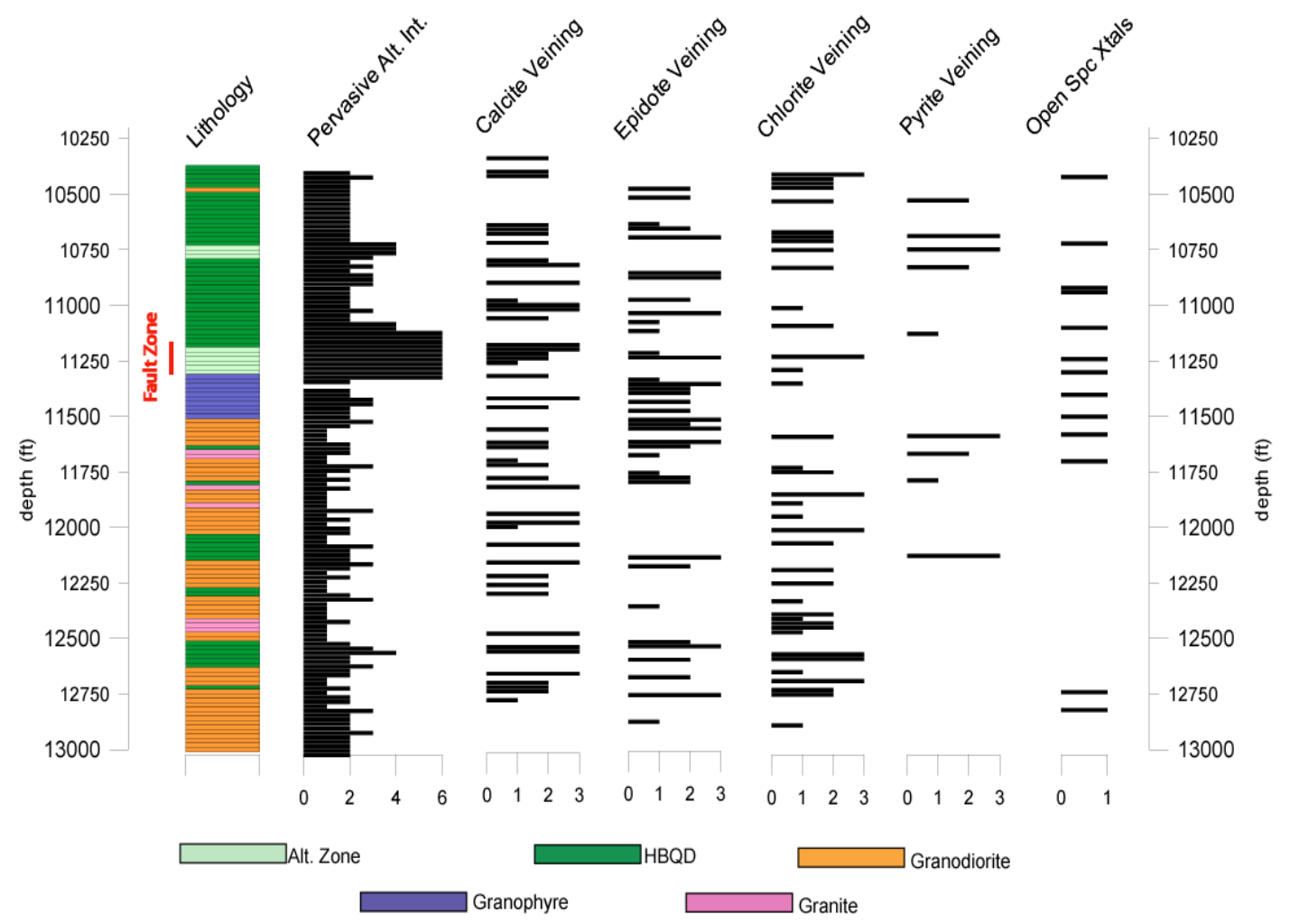

Fig. 11. Distributions of rock types, alteration intensity and hydrothermal minerals between depths of 2500 and 13,000 ft (762-3962 m) in well 46A-19RD. Lithology color code as follows: dark green $=$ hornblende biotite quartz diorite, yellow $=$ biotite quartz diorite, orange $=$ biotite granodiorite, pink $=$ granite, purple $=$ granophyre, light green $=$ alteration zone.

\section{Hydrothermal Alteration Zones and Vein Mineralization}

The altered zones can be readily identified in the chip samples by their green color and abundance of epidote, pyrite, chlorite, and white micas. This type of alteration occurs most commonly within narrow intervals of the hornblende biotite quartz diorite. Altered zones at about 6540 - $6560 \mathrm{ft}(1993-1999 \mathrm{~m})$ and 7940 - $8020 \mathrm{ft}(2420-2445 \mathrm{~m})$, correlate with zones of lost circulation.

The earliest vein assemblage consists of chlorite, epidote, pyrite, quartz, and minor sulfides (Fig. 12). This assemblage is characteristic of the oldest lithologies. The youngest assemblages are dominated by calcite \pm chlorite, quartz, hematite, and minor wairakite. Minerals typical of both the cap rock (smectite, illite-smectite) and reservoir (epidote, wairakite, illite) sections of other wells have been identified in 46A-19RD. Two generations of epidote appear to be present, a coarse-grained epidote that forms sealed veins within the quartz diorite and granodiorite, and vuggy veins containing small euhedral crystals of green epidote. These small euhedral crystals may represent a younger generation of mineralization, perhaps geothermal in age. Similar epidote has been encountered in nearby well 72-19. In this well wairakite, which is characteristic of 
geothermal systems, postdates the epidote at $6100 \mathrm{ft}(1859 \mathrm{~m})$. In general, temperatures implied by the minerals trend from hotter to cooler as time progresses. However, preliminary fluid inclusion studies on the youngest blocky calcite indicate temperatures consistent with the hot, present-day conditions.

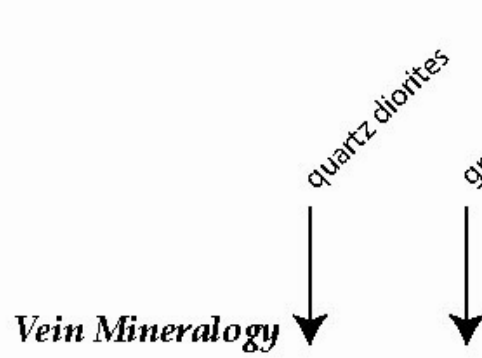

Hematite

Adularia

Calcite

Chlorite

Epidote

Pyrite

Quartz

"Wairakite

Pervasive Alt. Minerals

Illite
Illite-smectite
Smectite
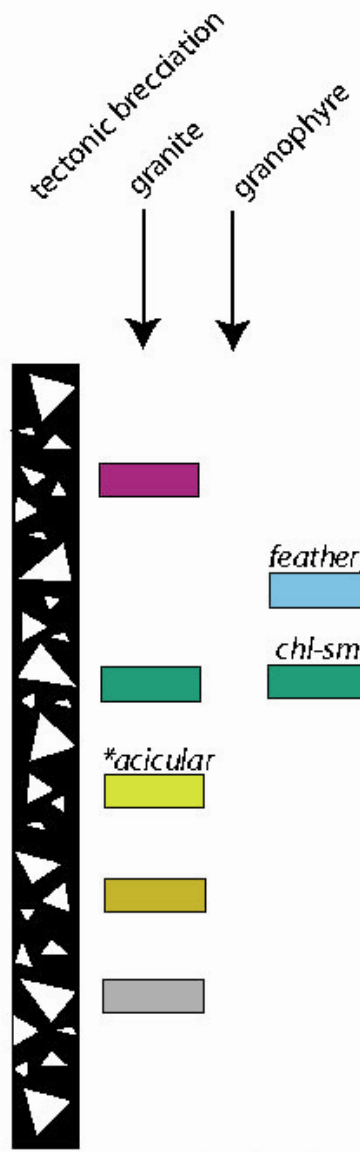

*acicular
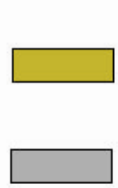

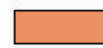

blocky

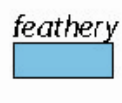

chi-sm?

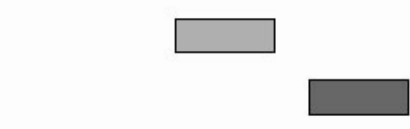

pervasive \&at depth intermediate

shallow

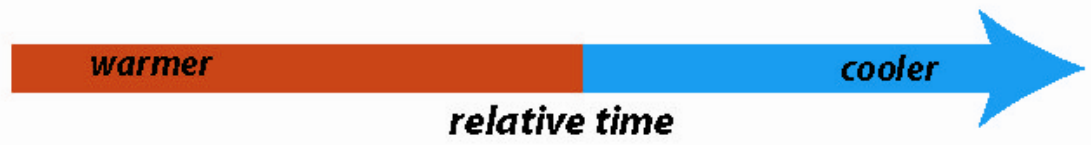

Fig. 12. The mineral paragenetic sequence based on observations from well 46A-19RD. Generally, the assemblages show a progression from hotter to cooler assemblages over time. See text for discussion. 


\section{Clay Mineralogy}

X-ray diffraction analyses of select samples over the depth of the well were conducted. The clay minerals smectite, kaolinite, interlayered illite-smectite, illite, chlorite, and chlorite-smectite were identified. A summary of the clay mineralogy vs. depth is shown in Figure 13. The present day temperature profile is shown at the left. In geothermal systems, smectite is considered stable up to temperatures of $180^{\circ} \mathrm{C}$ (Henley and Ellis, 1983), and interlayered illite-smectite to temperatures of $225^{\circ} \mathrm{C}$ (Henley and Ellis, 1983.) In comparison to the present temperature profile, smectite's disappearance is consistent with the $\sim 180^{\circ} \mathrm{C}$ depth. However, illite-smectite persists to depths where temperatures are much higher than $225^{\circ} \mathrm{C}$. The persistence of these clays may be due to recent heating, or possibly low permeabilities, which has hindered reequilibration of the rocks.

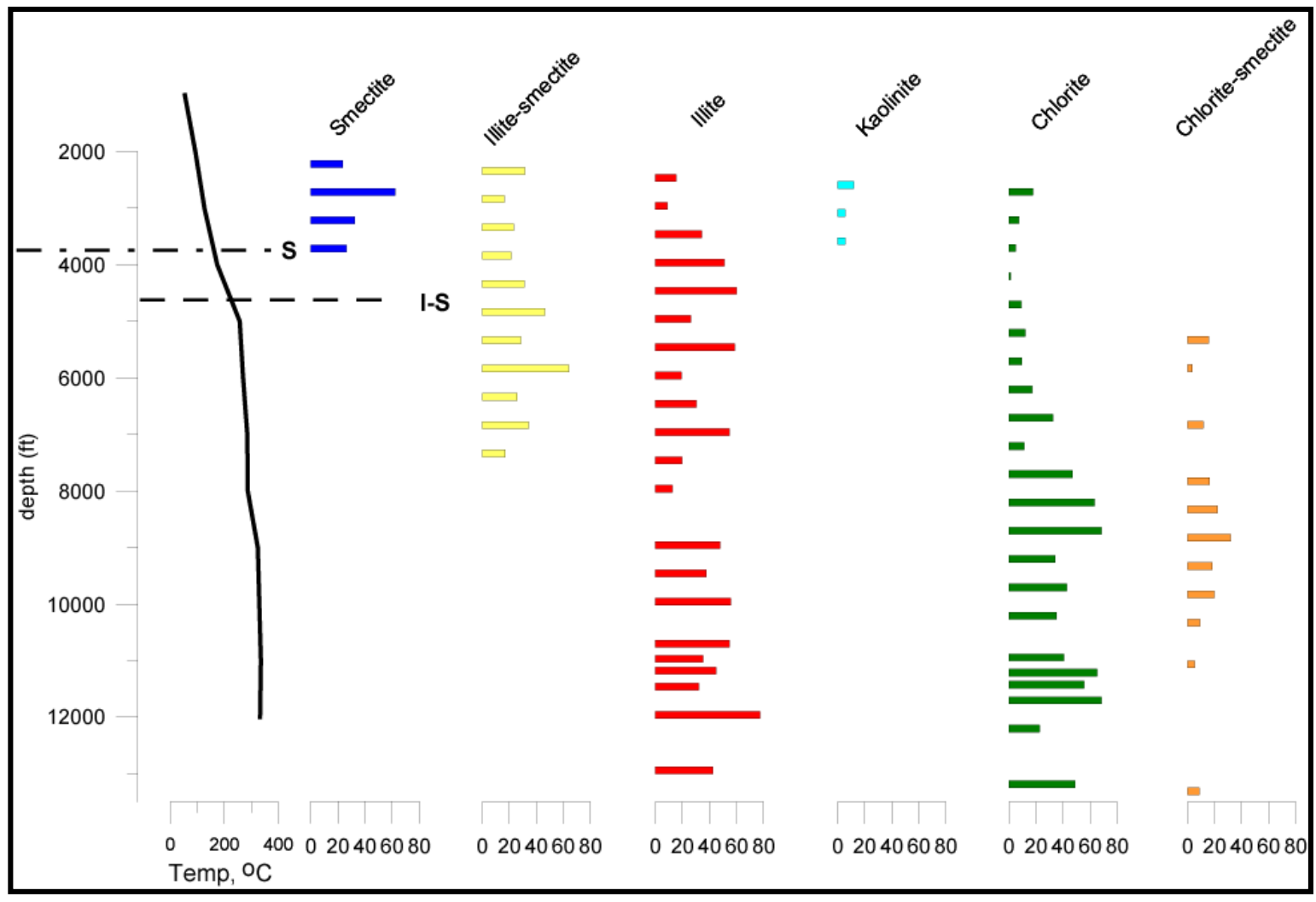

Fig. 13. Clay mineralogy as percent abundance of total clays versus depth for well 46A19RD. The present day temperature profile is shown at the left for comparison. See text for further discussion.

\section{The Target Zone: 10,000 ft to Depth}

The interval from 10,000 $\mathrm{ft}$ (3048 $\mathrm{m}$ ) to TD in the well is of special interest, as this is the target zone selected for stimulation by hydrofracturing. Although no lost circulation zones were encountered in this interval, there are indications that this zone was at least somewhat permeable in the past. 
Several zones containing tectonic breccia were identified in the well from petrographic analysis of the cuttings at depths greater than $9400 \mathrm{ft}(2865 \mathrm{~m})$. Frequently, both the feldspars and quartz are strained in these intervals. Zones of intense brecciation correlate with zones of strong alteration and/or increased veining. In many instances, the zones of tectonic brecciation are cut by veins of later calcite \pm quartz \pm adularia \pm chlorite (Fig. 14).

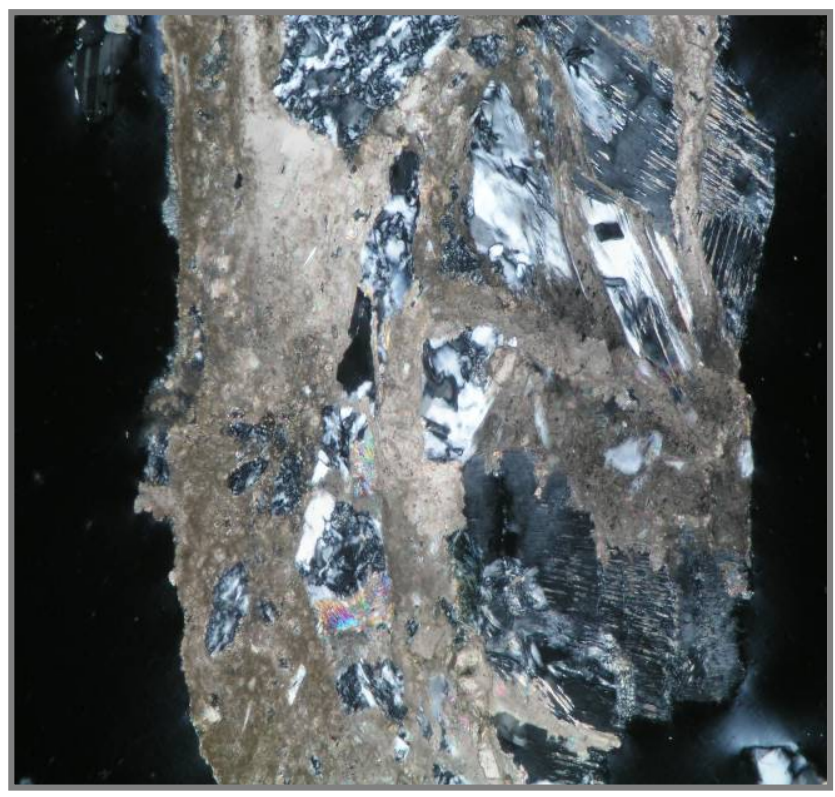

Fig. 14. Close-up of a calcite + chlorite vein in brecciated granodiorite.

In summary, the petrographic observations indicate that the most intensely brecciated and altered rocks in the zone targeted for stimulation (below 10,000 $\mathrm{ft}(3048 \mathrm{~m}$ )) occur between 11,200 and 11,350 ft (3414 and $3459 \mathrm{~m}$ ). This zone is interpreted as a shear zone that initially juxtaposed quartz diorite against granodiorite. Strong pervasive alteration and veining within the brecciated quartz diorite and granodiorite suggest this shear zone was permeable in the past. This zone of weakness was subsequently exploited by a granophyre dike whose top occurs at $11,350 \mathrm{ft}(3459 \mathrm{~m})$. The dike is essentially unaltered. We anticipate, based on the cuttings samples that failure during stimulation will most likely occur along this shear zone.

\section{The Salton Sea Geothermal System}

The Salton Sea geothermal system is developed in Quaternary deltaic sandstones and shales of the Salton Trough, the northern landward extension of the Gulf of California (Fig. 15; Hulen and Pulka, 2001). Quaternary volcanoes are exposed at Obsidian Butte, Rock Hill, Red Island and Mullet Island and several of the wells have encountered older rhyolite (Hulen and Pulka, 2001). Injection well Elmore IW3 RD-1 was drilled in 1988 and used for injection until 1997. Fluids injected into Elmore IW3 RD-1 were 
hypersaline (TDS exceeds 220,000 mg/kg) and metal-rich, but low in silica, which was removed prior to injection. The well was deepened in 1997 from 2308 to $2405 \mathrm{~m}$ depth due to declining performance and renamed Elmore IW3 RD-2.

\section{Occurrence of Scale Deposits Within the Reservoir Rocks}

A variety of scale deposits have been recognized in the cuttings from Elmore IW3 RD-2 based on their mineralogy and textures. Concentrations of scale occur primarily at the top of the redrill at a depth of approximately $2308 \mathrm{~m}$ and sporadically at greater depths (Fig. 16). Petrologic, SEM, and semiquantitative energy dispersive (EDX) analyses were used to determine the mineralogy and texture of the scale deposits found in the cuttings. Fluid inclusions were studied in associated euhedral calcite crystals to determine their petrogenesis.

Photomicrographs of scale deposits show distinct mineral banding that range from tens to hundreds of micrometers in thickness (Fig. 17; McLin et al., 2006c). SEM and EDX analyses demonstrate that the scale deposits consist of layers of barite and fluorite associated with minor anhydrite, amorphous silica and copper arsenic sulfides. Some bands of barite show strong Ti peaks in the EDX spectra, whereas amorphous silica bands show strong Fe peaks in the spectra. No differences in the chemistries of adjacent barite bands, was observed, suggesting that factors other than fluid chemistry control barite deposition. The anhydrite coats the barite, whereas the amorphous silica was found deposited on the copper arsenic sulfide scale.

Secondary fluid inclusions were studied in euhedral calcite crystals from a depth of 2308 $\mathrm{m}$. Only two-phase liquid-rich inclusions were observed. The homogenization temperatures of thirty inclusions ranged from $337^{\circ}$ to $357^{\circ} \mathrm{C}$. These temperatures represent the minimum trapping temperatures. Ice-melting temperatures indicate salinities between 23 and 25 weight percent $\mathrm{NaCl}-\mathrm{CaCl}_{2}$ equivalent. These homogenization temperatures indicate that the calcite crystals were not formed as scale deposits, as these temperatures are much higher than the $110^{\circ} \mathrm{C}$ and $258^{\circ} \mathrm{C}$ temperatures of the injected fluid and the reservoir respectively.

The composition of the reservoir fluid was estimated from the composition of the production fluids from the Unit 6 Obsidian Butte well (Table 7). The fluid has an ionic strength of 2.2 M. Fe and Mg values were estimated from data tabulated by Hulen et al. (2004). Initial fluid compositions were calculated by equilibrating the reservoir fluid composition with each fluid regime at $258^{\circ} \mathrm{C}$, the initial reservoir temperature. The 
Table 7. Composition of Unit 6 Obsidian Butte well.

\begin{tabular}{|c|c|}
\hline Chemical Component & $\mathrm{Mol} / \mathrm{kg}$ \\
\hline $\mathrm{SiO}_{2}$ & $.9962 \mathrm{E}-2$ \\
\hline $\mathrm{Na}^{+}$ & .1957 \\
\hline $\mathrm{K}^{+}$ & .3325 \\
\hline $\mathrm{Ca}^{2+}$ & $.6137 \mathrm{E}-1$ \\
\hline $\mathrm{Mg}^{2+}$ & $.1781 \mathrm{E}-5$ \\
\hline $\mathrm{Cl}^{-}$ & 3.944 \\
\hline $\mathrm{F}^{-}$ & $.1053 \mathrm{E}-2$ \\
\hline $\mathrm{HCO}_{3}^{-}$ & $.1506 \mathrm{E}-2$ \\
\hline $\mathrm{SO}_{4}^{-}$ & $.1040 \mathrm{E}-2$ \\
\hline $\mathrm{Fe}^{+2}$ & $.2586 \mathrm{E}-6$ \\
\hline $\mathrm{Mg}^{+2}$ & $.1781 \mathrm{E}-5$ \\
\hline $\mathrm{Ba}^{+2}$ & $.1310 \mathrm{E}-2$ \\
\hline $\mathrm{pH}$ & 4.5 \\
\hline
\end{tabular}




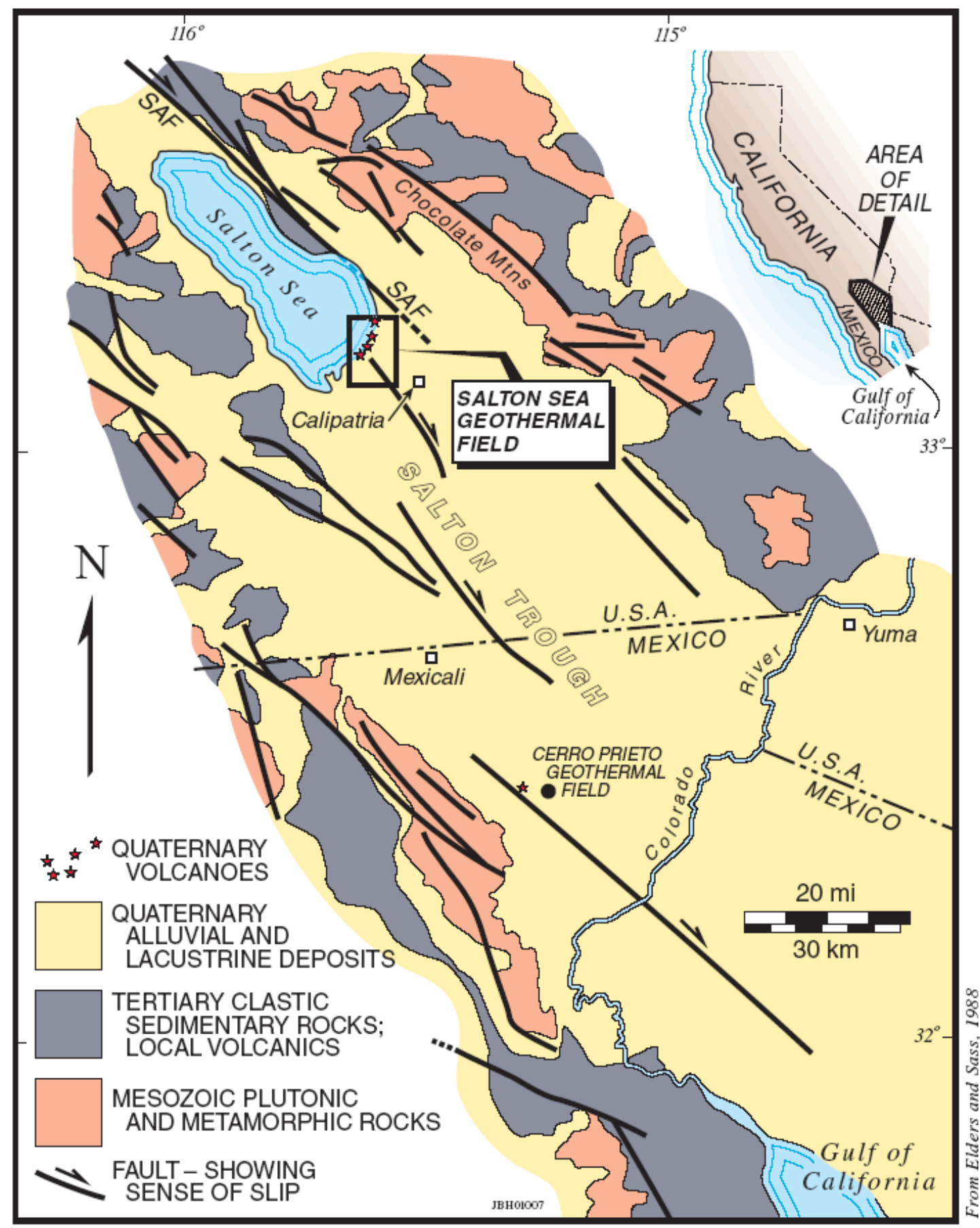

Fig. 15. Generalized geologic map of the Salton trough from Hulen et al., 2001. 


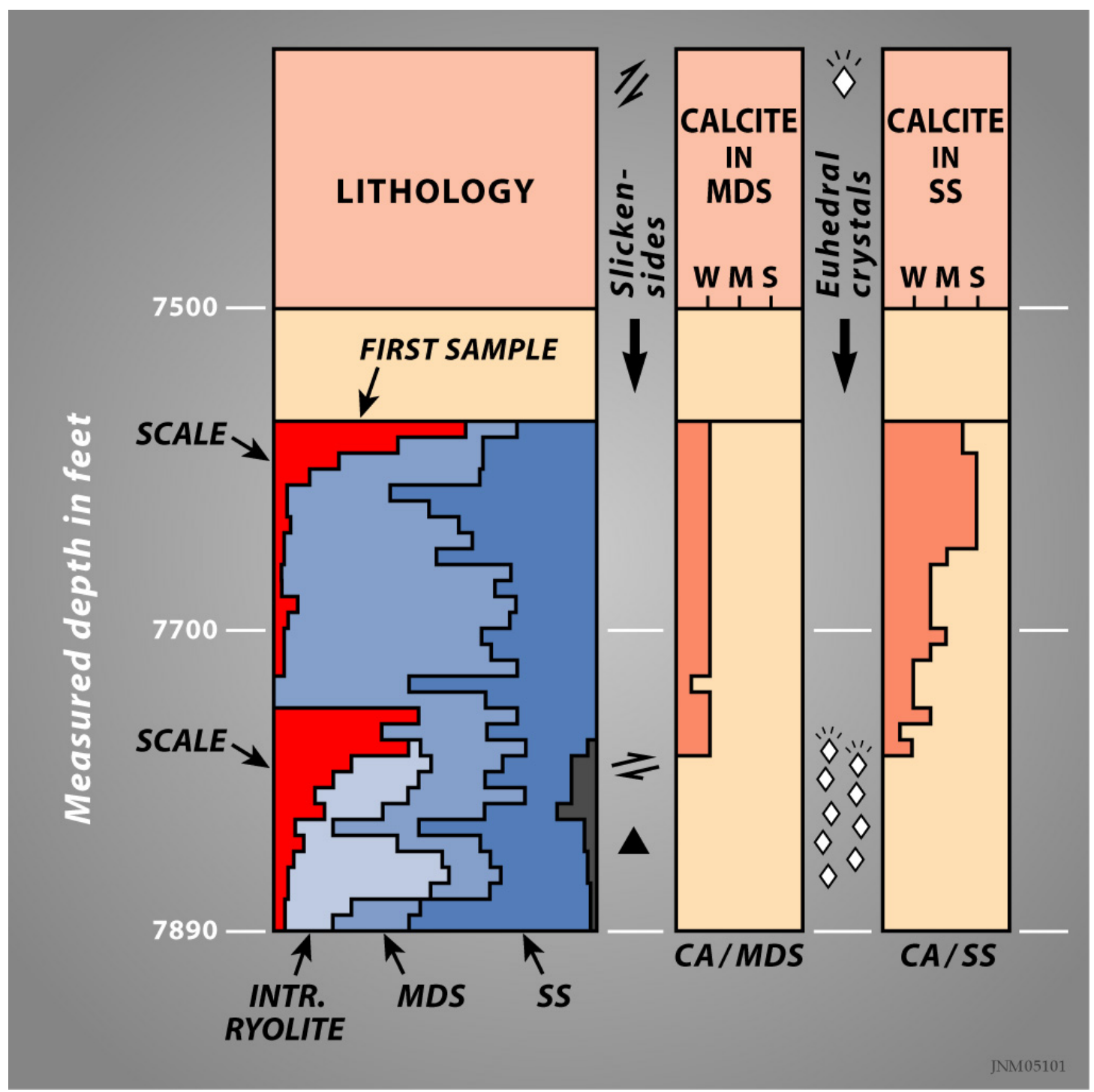

Fig. 16. Lithology of cuttings from Elmore IW3 RD-2 and calcite concentration, as well as the location of euhedral crystals and slickensides.

injectate composition was not allowed to change over time.

\section{Geochemical Modeling of Fluid Rock Interactions}

Geochemical simulations were carried out using the non-isothermal reactive geochemical transport code TOUGHREACT. An extended Debye-Huckel equation (after Helgeson et al., 1981) was used in this study for calculating the activity of aqueous species. Our conceptual model considers a one dimensional flow tube beginning at the injection well and extending outward for $500 \mathrm{~m}$. The simulations were run for a total of 7 years. Changes in fluid $\mathrm{pH}$, fracture porosity, fracture permeability, fluid temperature, and mineral abundances were monitored. Mineral abundance changes are reported in terms of changes in volume fraction of quartz, potassium feldspar, chlorite, illite, sodium 

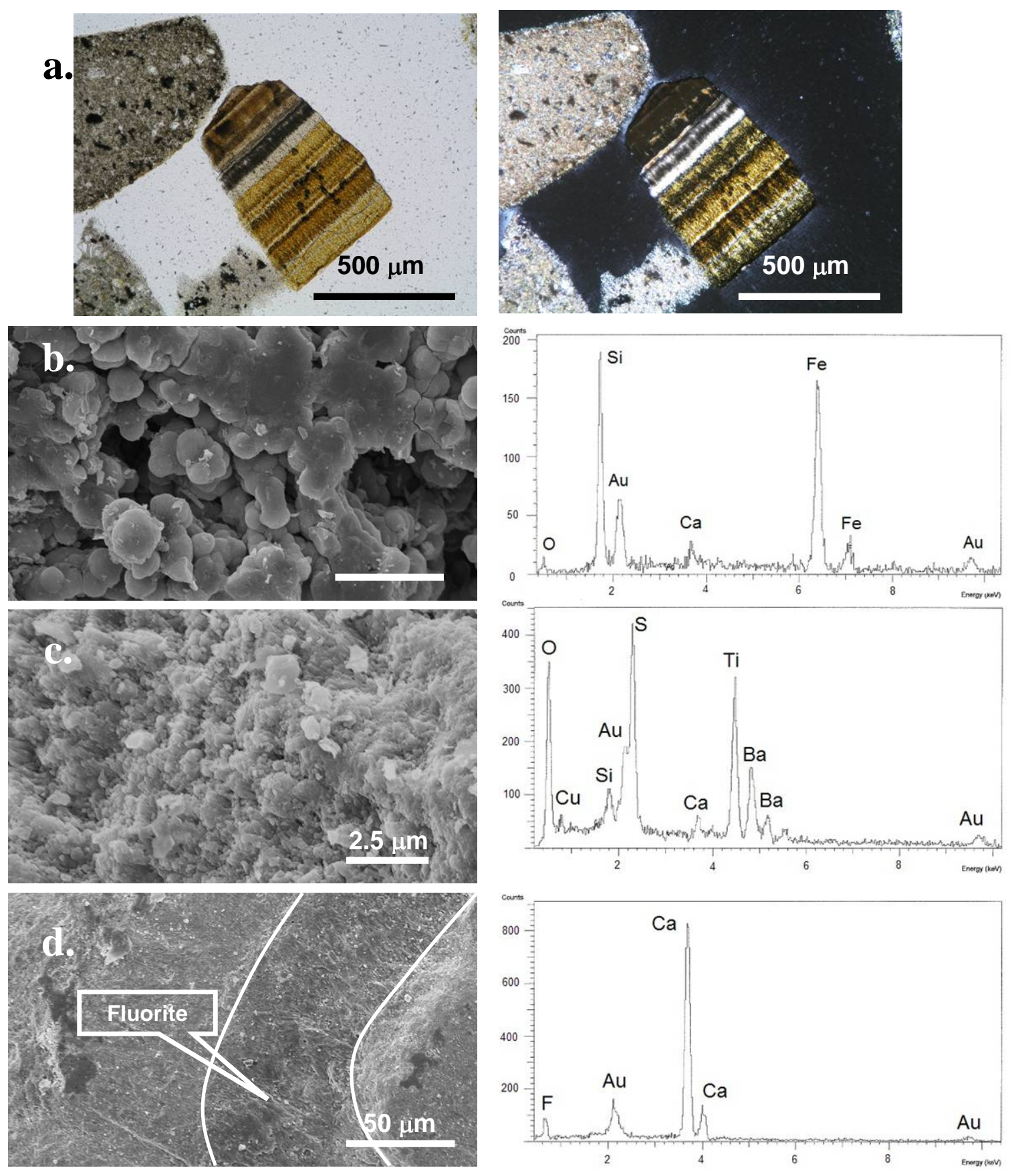

Fig. 17. (a) Photomicrographs of scale deposits from Elmore IW3 RD sampled from 2308-2405 m depth. Images taken under plane polarized light (left) and under crossed nicols (right). (b), (c), (d) SEM and corresponding EDX spectra for (b) amorphous silica (c) barite and (d) fluorite from scale deposits. 
smectite, calcium smectite, calcite, dolomite, anorthite, biotite, amorphous silica, anhydrite, barite and fluorite. Calcite, barite, fluorite, anhydrite, quartz and amorphous silica displayed the most significant changes. Changes in porosity were calculated as a function of mineral dissolution and precipitation. Porosity increases when mineral dissolution is dominant, whereas porosity decreases when precipitation dominates. Changes in permeability are calculated from changes in porosity as described above.

Several different geochemical scenarios were simulated. In the initial model, the composition of the injected fluid was the same as the production fluid. The model results indicate that the deposition of amorphous silica, calcite, and quartz would be responsible for the porosity declines in Elmore IW3 RD. Barite and fluorite are minor precipitates, whereas anhydrite dissolves. As in the alternative models, fluorite precipitation continues after deposition of barite ceases. This model does not fit the observed mineralogy of the scales.

In the second simulation, the concentration of $\mathrm{SiO}_{2}$ in the injection fluid was reduced to $10^{-22}$, reflecting precipitation of $\mathrm{SiO}_{2}$ prior to injection. In this case, amorphous $\mathrm{SiO}_{2}$ does not precipitate, but a minor amount of quartz dissolves and then reprecipitates. Thus, the amorphous $\mathrm{SiO}_{2}$ must be carried in the injection fluid and could not be derived through dissolution of the reservoir rock. In contrast to the initial model, Figure 18 shows that significant barite and calcite and minor fluorite precipitate. However, barite precipitation reaches a maximum at a later time, compared to the initial model.

Figure 19 shows the results of reducing both silica and $\mathrm{HCO}_{3}{ }^{-}$concentrations in the injection fluid. Reducing $\mathrm{HCO}_{3}{ }^{-}$in the injection fluid to trace amounts eliminates calcite precipitation, consistent with the observed scale mineralogy. In this model, barite and fluorite are the dominant phases precipitated, with fluorite deposition continuing after barite deposition ceases. This model results in the greatest amount of barite precipitation, which reaches a maximum value at still greater times than in the second model. Thus, this model best explains the observed mineral banding of the scale deposits.

The modeled results most closely simulate the observed mineral deposits based on observations of the cuttings samples when $\mathrm{SiO}_{2}$ and $\mathrm{HCO}_{3}{ }^{-}$are reduced to trace amounts in the injection fluid. Because minor amounts of amorphous $\mathrm{SiO}_{2}$ are found in the scale deposits, the model indicates that amorphous silica must at times be present in the injection fluid. 

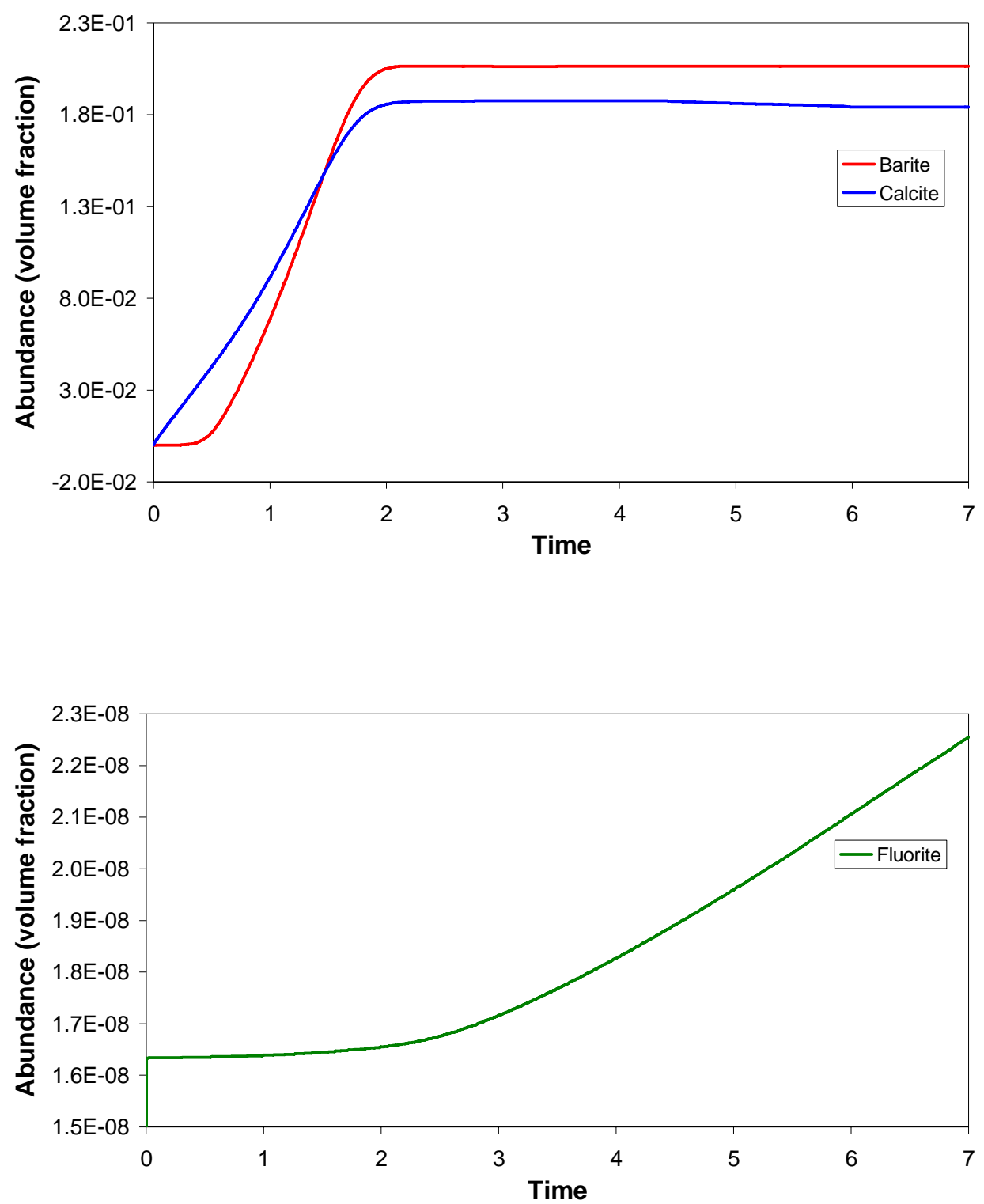

Figure 18. Graphs showing barite, calcite, and fluorite precipitation over time for the case in which $\mathrm{SiO}_{2}$ is removed from the injection fluid. 

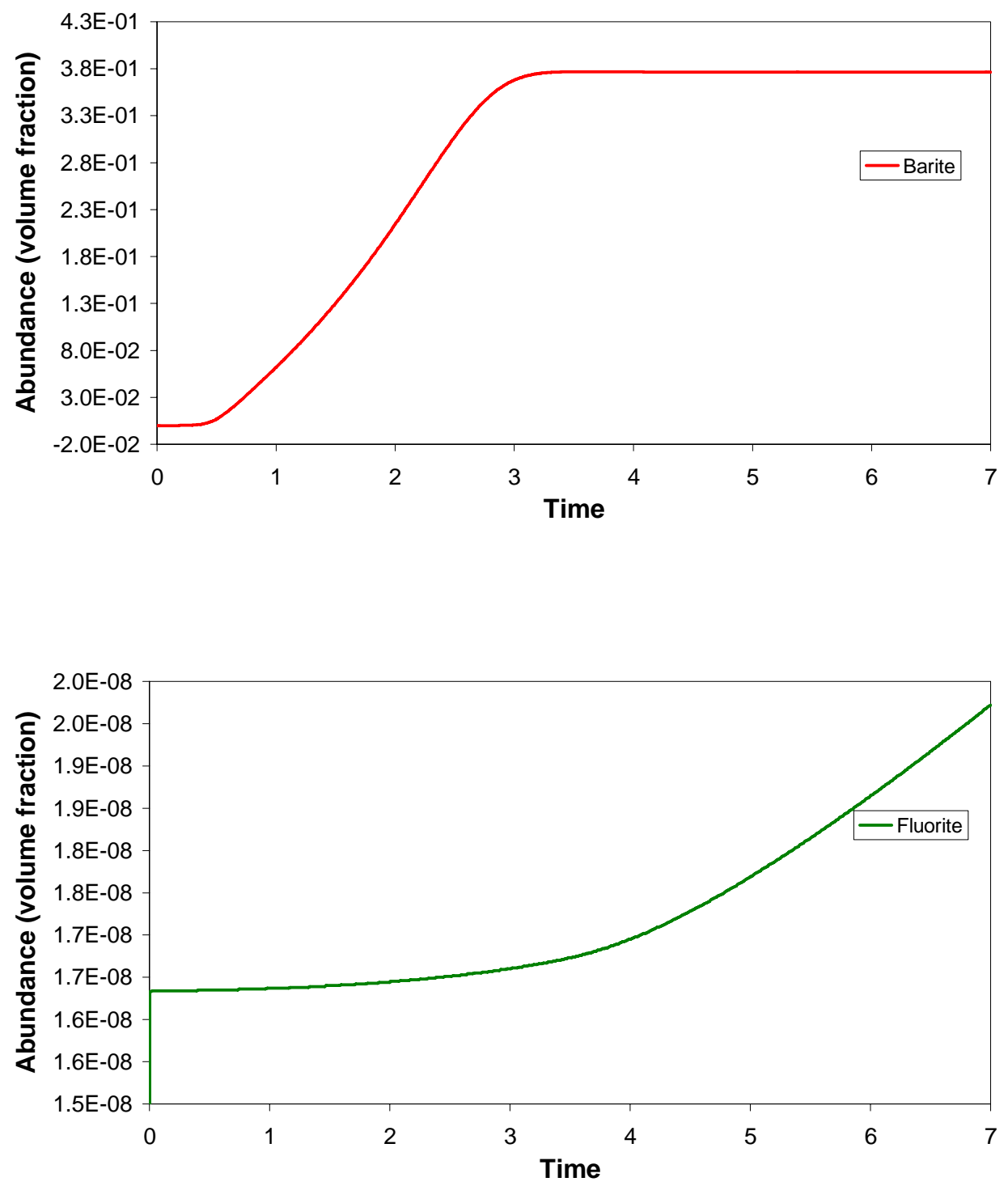

Fig. 19. Graphs showing barite and fluorite precipitation over time for the model with silica and bicarbonate removed from the injection fluid.

\section{Reports Resulting from this Project}

Dilley, L, Norman, D.I., Moore, J. and McCulloch, J., (2006). "Fluid stratigraphy and permeable zones of the Coso geothermal reservoir". Geothermal Resources Council Transactions, v. 30, p. 127-131.

Kovac, K.M., Moore J.N., Rose P.E. and McCulloch J. (2006) "Geology of injection well 46A-19RD in the Coso Enhanced Geothermal Systems experiment." Geothermal Resources Council Transactions, v. 30, p. 139-143. 
McLin, K.S., Moore, J.N., Hulen, J., Bowman, J.R., Berard, B. (2006a) "Mineral characterization of scale deposits in injection wells; Coso and Salton Sea geothermal fields, CA.” Proceedings, $31^{\text {st }}$ Workshop on Geothermal Reservoir Engineering.

McLin, K.S., Kovac, K.M., Moore, J.N., Adams, M.C., Xu, T. (2006b) "Modeling the Geochemical Effects of Injection at Coso Geothermal Field, CA; Comparison with Field Observations” Proceedings, $31^{\text {st }}$ Workshop on Geothermal Reservoir Engineering.

McLin, K.S., Kovac, K.M., Moore, J.N., Kaspereit, D., Berard, B., Xu, T., McLin, R.H., Hulen, J.B. (2006c) "Modeling the Geochemical Effects of injection at Salton Sea geothermal field, California: comparison with field observations.” Geothermal Resources Council Transactions, v. 30, 507-511.

Norman, D.I, Dilley, L, McLin, K.m and Moore, J.N., (2006), "Applying fluid inclusion stratigraphy analyses to geothermal systems." $16^{\text {th }}$ V. M. Goldschmidt Conference, Melbourne, Australia, 27 August-01 September 2006.

Park, J., Norman, D., McLin, K. and Moore, J. (2006) "Modeling amorphous silica precipitation: a strategy to reduce silica precipitation near Coso injection wells." Proceedings, $29^{\text {th }}$ Workshop on Geothermal Reservoir Engineering, Stanford University.

\section{References}

Adams, M.C., Moore, J.N., Bjornstad, S., and Norman, D.I. (2000) "Geologic history of the Coso geothermal system.” Geothermal Resources Council Transactions, v. 24, p. 205209.

Bachler, D. (2003) "Coupled thermal-hydraulic-chemical modeling at the Soultz-sousForets HDR reservoir" (France). PhD dissertation, Swiss Federal Institute of Technology, Zurich, Switzerland.

Dilley, L, Norman, D.I., Moore, J. and McCulloch, J., (2006). "Fluid stratigraphy and permeable zones of the Coso geothermal reservoir”. Geothermal Resources Council Transactions, v. 30, p. 127-131.

Durst, D. (2002) "Geochemical modeling of the Soultz-sous-Forets hot dry rock test site: Coupled fluid-rock interaction to heat and fluid transport.” PhD dissertation, Universite de Neuchatel, France.

Fournier, R.O. (1985) "The behavior of silica in hydrothermal solutions" in: B.R. Berger and P.M. Bethke, eds., Geology and Geochemistry of Epithermal Systems, Reviews in Economic Geology, v. 2, Society of Economic Geologists, p. 45-61.

Gunnarsson, I. and Arnorsson, S. (2000) "Amorphous silica solubility and the thermodynamic properties of $\mathrm{H}_{4} \mathrm{SiO}_{4}{ }^{\circ}$ in the range of $0^{\circ}$ to $350^{\circ} \mathrm{C}$ at $\mathrm{P}_{\text {sat." }}$ Geochimica and Cosmochimica Acta, v. 64, 2295-2307. 
Helgeson, H.C., Kirkham, D.H., Flowers, D.C. (1981) “Theoretical prediction of the thermodynamic behavior of aqueous electrolytes at high pressures and temperatures: IV. Calculation of activity coefficients osmotic coefficients, and apparent molal and standard and relative partial molal properties to $600^{\circ} \mathrm{C}$ and $5 \mathrm{~kb}$.” American Journal of Science, v. 281, 1249-1516.

Hulen, J.B. and Pluka, F.S. (2001) "Newly-discovered, ancient extrusive rhyolite in the Salton Sea geothermal field, Imperial Valley, Californial.” Proceedings, $26^{\text {th }}$ Workshop on Geothermal Reservoir Engineering.

Hulen, J.B., Norton, D.L., Moore, J.N., Kaspereit, D. (2004) "Epithermal vein-hosted and stratabound $\mathrm{Pb}-\mathrm{Zn}$ mineralization in an active hydrothermal system: the southern Salton Sea geothermal field, California.” Geothermal Resources Council Transactions, 28, 415424.

Iler, R.K. (1979) The Chemistry of Silica-Solubility, Polymerization, Colloid, and Surface Properties, and Biochemistry. John Wiley \& Sons, Inc., New York.

Kovac, K.M., Moore, J.N., and Lutz, S.J. (2005) "Geologic framework of the East Flank, Coso geothermal field: Implications for EGS Development.” Proceedings, $30^{\text {th }}$ Workshop on Geothermal Reservoir Engineering.

Kovac K.M., Moore J.N., Rose P.E. and McCulloch J. (2006) “Geology of injection well 46A-19RD in the Coso Enhanced Geothermal Systems experiment." Geothermal Resources Council Transactions, v. 30, p. 139-143.

Lutz, S.J., and Moore, J.N. (1997) "Petrographic and X-ray diffraction study of 130 cuttings samples from six wells in the Coso geothermal area, California,” unpublished CalEnergy Corporation Report.

Lynne, B.Y., Campbell, K.A. (2004) "Morphologic and mineralogic transitions from opal-A to opal-CT in low-temperature siliceous sinter diagenesis, Taupo Volcanic zone, New Zealand.” Journal of Sedimentary Research, v. 74, n. 4, p. 561-579.

McLin, K.S., Moore, J.N., Hulen, J., Bowman, J.R., Berard, B. (2006a) "Mineral characterization of scale deposits in injection wells; Coso and Salton Sea geothermal fields, CA.” Proceedings, $31^{\text {st }}$ Workshop on Geothermal Reservoir Engineering.

McLin, K.S., Kovac, K.M., Moore, J.N., Adams, M.C., Xu, T. (2006b) “Modeling the Geochemical Effects of Injection at Coso Geothermal Field, CA; Comparison with Field Observations” Proceedings, $31^{\text {st }}$ Workshop on Geothermal Reservoir Engineering.

McLin, K.S., Kovac, K.M., Moore, J.N., Kaspereit, D., Berard, B., Xu, T., McLin, R.H., Hulen, J.B. (2006c) "Modeling the Geochemical Effects of injection at Salton Sea geothermal field, California: comparison with field observations.” Geothermal Resources Council Transactions, v. 30,507-511. 
Norman, D.I, Dilley, L, McLin, K.m and Moore, J.N., (2006), “Applying fluid inclusion stratigraphy analyses to geothermal systems." $16^{\text {th }}$ V. M. Goldschmidt Conference, Melbourne, Australia, 27 August-01 September 2006.

Park, J., Norman, D., McLin, K. and Moore, J. (2006) "Modeling amorphous silica precipitation: a strategy to reduce silica precipitation near Coso injection wells." Proceedings, $29^{\text {th }}$ Workshop on Geothermal Reservoir Engineering, Stanford University.

Pruess, K., Oldenburg, C., Moridis, G., 1999. TOUGH2 user's guide, Version 2.0. Lawrence Berkeley Laboratory Report LBL-43134, Berkeley, California.

Palandri, J.L. and Kharaka, Y.K. (2004). A compilation of rate parameters of watermineral interaction kinetics for application to geochemical modeling. U.S. Geological Survey Open File Report 2004-1068.

Rodgers, K.A., Browne, P.R.L., Buddle, T.F., Cook, K.L., Greatrex, R.A., Hampton, W.A., Herdianita, N.R., Holland, G.R., Lynne, B.Y., Martin, R., Newton, Z., Pastars, D., Sannazarro, K.L., Teece, C.I.A. (2004) "Silica Phases in sinters and residues from geothermal fields of New Zealand.” Earth Science Reviews, v. 66, p. 1-61.

Vinsome, P. K. W., and J. Westerveld, 1980. A simple method for predicting cap and base rock heat losses in thermal reservoir simulators. Journal of Canadian Petroleum Technology, v. 19 (3), 87-90.

$\mathrm{Xu}, \mathrm{T}$. and Pruess, K. (2001) "Modeling multiphase non-isothermal fluid flow and reactive geochemical transport in variably saturated fractured rocks: 1. Methodology." American Journal of Science, v. 301, 16-33.

Xu, T. and Pruess, K. (2004) "Numerical simulation of injectivity effects of mineral scaling and clay swelling in a fractured geothermal reservoir." Geothermal Resources Council Transcations, v. 28, 269-276.

Xu, T., Sonnenthal, E., Spycher, N., and Pruess, K. (2004) “TOUGHREACT user's guide: A simulation program for non-isothermal multiphase reactive geochemical transport in variably saturated geologic media.” Lawrence Berkeley National Laboratory publication LBNL-55460. 